\title{
Essay
}

\section{Juries and Race in the Nineteenth Century}

\author{
James Forman, Jr. ${ }^{\dagger}$
}

How can justice be administered throughout States thronging with colored fellow-citizens unless you have them on the juries?

- Charles Sumner ${ }^{1}$

\section{INTRODUCTION}

The Supreme Court's jurisprudence on criminal juries has overlooked an important piece of history. This is most notable in the context of its jury discrimination jurisprudence over the past twenty years. In Batson $v$. Kentucky, the Court held that the Equal Protection Clause prohibits a prosecutor from using his peremptory strikes against a potential juror on the basis of race. ${ }^{2}$ Later, the Court extended Batson to a variety of related contexts. In Powers v. Ohio, the Court held that Batson applied even when the defendant and the juror were of different races, holding that a white

$\dagger$ Associate Professor of Law, Georgetown University Law Center. I would like to thank the following people for their helpful comments: Alex Aleinikoff, Miles Ehrlich, Phoebe Ellsworth, Arthur Evenchik, Sam Gross, Emma Coleman Jordan, Neal Katyal, Ellen Katz, Robin Lenhardt, Sandy Levinson, David Luban, Jim Oldham, Rebecca Scott, Michael Seidman, Gerry Span, Alison Tucher, Bill Vukowich, Robin West, and especially Akhil Amar. I would also like to thank the participants at the Yale Legal History Forum and the Georgetown Faculty Workshop. Margaret Rodgers provided outstanding research assistance, and Tracey Bridgman and her staff at the Edward Bennett Williams Law Library were wonderful.

1. Cong. Globe, 42d Cong., 2d Sess. 822 (1872) (statement of Sen. Sumner).

2. 476 U.S. 79 (1986). 
defendant could challenge the discriminatory striking of black jurors. ${ }^{3}$ The Equal Protection Clause prohibits discrimination only by state actors, but in Edmonson v. Leesville Concrete Co., the Court held that private civil litigants were to be regarded as state actors when they used their peremptory strikes. ${ }^{4}$ The Court went one step further in Georgia v. McCollum, holding that even criminal defendants were state actors when exercising peremptories. ${ }^{5}$

These cases prompted disagreement among the Justices on important questions, including whether a juror's race might influence his view of a case. In Powers, Justice Kennedy flatly rejected such a notion, arguing that to accept it would be to recognize "the very stereotype the law condemns." His conclusion in Edmonson was similarly resounding: Our "progress as a multiracial democracy" mandates that litigants "satisfy themselves of a jury's impartiality without using skin color as a test."7 While Kennedy's position has consistently held a majority of the Court, Justice O'Connor has taken the opposite view: "We ought not delude ourselves that the deep faith that race should never be relevant has completely triumphed over the painful social reality that, sometimes, it may be."

Also in dispute has been the question of whose rights are violated by discriminatory jury selection. The prevailing view, again pressed most vigorously by Justice Kennedy, is that there are three harms: to the defendant, to the excluded juror, and to the community at large. ${ }^{9}$ This rationale has allowed the Court to extend Batson to all parties in all trials, because whenever a litigant uses a discriminatory strike, somebody is harmed. Again, this view has been challenged, with Justices O'Connor, Scalia, and Thomas arguing that only criminal defendants were meant to be protected by the rule against discriminatory strikes. ${ }^{10}$ In McCollum, for example, Thomas wrote that prohibiting a defendant from using race-based peremptory strikes "exalted the right of citizens to sit on juries over the rights of the criminal defendant, even though it is the defendant, not the jurors, who faces imprisonment or even death." 11

3. 499 U.S. 400 (1991).

4. 500 U.S. 614 (1991).

5. 505 U.S. 42 (1992).

6. 499 U.S. at 410.

7. 500 U.S. at 630; see also McCollum, 505 U.S. at 59 ("This Court firmly has rejected the view that assumptions of partiality based on race provide a legitimate basis for disqualifying a person as an impartial juror.").

8. Brown v. North Carolina, 479 U.S. 940, 941 (1986) (O'Connor, J., concurring in denial of certiorari); see also id. at 941-42 ("That the Court will not tolerate prosecutors' racially discriminatory use of the peremptory challenge, in effect, is a special rule of relevance, a statement about what this Nation stands for, rather than a statement of fact.").

9. Powers, 499 U.S. at 406.

10. See McCollum, 505 U.S. at 60-62 (Thomas, J., concurring in the judgment); id. at 68-69 (O'Connor, J., dissenting); Powers, 499 U.S. at 418 (Scalia, J., dissenting).

11. 505 U.S. at 62 (Thomas, J., concurring in the judgment). 
On its face, this line of cases evokes the legacy of Reconstruction, when racial inclusiveness on juries was a major constitutional and legislative issue. In deciding these cases, however, the Court has rarely examined debates from that period. ${ }^{12}$ This Essay attempts to provide what is missing from the Court's jury discrimination decisions: a discussion of how various parties during the antebellum and Reconstruction eras thought about juries, and especially how they thought about juries and race. ${ }^{13}$ In Part II, I focus on the abolitionists' views of the jury. I suggest that while the Court has traditionally recognized the primacy of juries to the political philosophy of the colonial era, juries became even more important during the abolitionist movement. Specifically, the abolitionists' struggle against fugitive slave laws deepened their commitment to jury trial-a commitment that had existed in some form since colonial times.

The abolitionists' struggle also helped set the stage for developments during the Reconstruction era, the subject of Part III. During Reconstruction, I argue, the abolitionist belief in juries as protectors of liberty came under challenge. After the Civil War, all-white Southern juries refused to indict or convict white defendants accused of crimes against blacks. In response, Reconstruction Republicans did not abandon the jury trial. Instead, they worked to eliminate barriers to black participation in the legal system, with a view toward ultimately securing the right of blacks to serve as jurors. They had come to recognize that the exclusion of blacks from juries made it impossible to achieve justice in Southern courts.

But just as important as the abolitionists' decision to end discriminatory jury selection was their reason for doing so. Blacks and Reconstruction Republicans were grappling with many of the issues that divide the Court today. One was the question of whose rights were violated by discriminatory selection. On this point, the historical record yields no single answer - different legislators took differing positions. But a common theme does emerge: The greatest legal injustice of the era was the failure to protect black victims of white violence, and most of the jury arguments were framed with that problem in mind.

12. The history of the jury trial after the enactment of the Bill of Rights has received as little attention from scholars as it has from the Court. See Albert W. Alschuler \& Andrew G. Deiss, A Brief History of the Criminal Jury in the United States, 61 U. CHI. L. REV. 867, 867-68 (1994) ("[T]he history of the criminal jury in the United States during the two hundred years following the enactment of the Bill of Rights has been the subject of astonishing scholarly neglect."). In addition, the Reconstruction era was long neglected by generations of historians who thought of it as an illegitimate period, "presided over by unscrupulous 'carpetbaggers' from the North, unprincipled Southern white 'scalawags,' and ignorant freedmen." ERIC FONER, RECONSTRUCTION: AMERICA'S UNFINISHED REVOLUTION, 1863-1877, at xix (1988).

13. In this respect, I join others who assert Reconstruction's centrality to legal history and constitutional theory. See, e.g., 1 BRUCE ACKeRman, We the PeOPle: Foundations 81-104 (1991); AKHIL ReEd AMAR, THE Bill of Rights: CREATION AND RECONSTRUCTION 163-294 (1998). 
Consideration of this historical reality would go a long way to resolving the debate presented in McCollum, where the Court struggled over whether white defendants charged with assaulting black victims could use their strikes to remove blacks from the jury. Writing for the Court, Justice Blackmun held that they could not, but in doing so he failed to refer to any of the evidence that protecting black victims from all-white juries was one of Reconstruction's goals. ${ }^{14}$ Blackmun's ahistoricism was matched by the revisionism of Justice Thomas, who argued in concurrence that protecting black defendants was the sole goal of Reconstruction. ${ }^{15}$ Again, as we shall see, the historical record says otherwise.

On another question, the Reconstruction debates provide even greater clarity. Reconstruction Republicans would be quite surprised by the current Court majority's assumption that a juror's race is irrelevant to how that juror is likely to perceive evidence, evaluate witnesses, or make judgments in a case. Reconstruction Republicans' case for racially diverse juries was grounded in the understanding that people's life experiences were significantly influenced by their race, and that these experiences, in turn, often made a difference in how they performed as jurors. So while the current majority believes that eliminating jury discrimination must be predicated on the belief that race is irrelevant, Reconstruction Republicans fought to end jury discrimination because of their contrary belief that race is significant. Accordingly, I conclude by suggesting that if the Court were to give more attention to Reconstruction, it would find a basis for its jury discrimination holdings that is more firmly rooted in history and more consistent with the emerging empirical evidence about race and juries.

\section{The ABolitionists, The Fugitive Slave LAWS, AND the JURY}

To understand Reconstruction, we must pay careful attention to abolition, for the Reconstruction Amendments grew out of the political and constitutional theory of the abolitionists. ${ }^{16}$ This is especially true when considering the right to jury trial, for the jury was of central concern both before and after the Civil War. While the Court has long understood the

14. See McCollum, 505 U.S. at 48-55, 59.

15. See id. at 61 (Thomas, J., concurring in the judgment) (criticizing the Court for abandoning Strauder $v$. West Virginia's focus on black defendants in favor of a rule protecting the right of black citizens to sit on juries).

16. See David A.J. Richards, Abolitionist Political and Constitutional Theory and the Reconstruction Amendments, 25 LOY. L.A. L. REV. 1187, 1187 (1992); see also JACOBUS TENBROEK, EQUAL UNDER LAW 28 (1965) (arguing that Fourteenth Amendment historians have erred by focusing solely on the Reconstruction Congress, and suggesting that the proper scope of historical inquiry must include "doctrines and political activities of the organized abolitionist movement"). 
centrality of the right to jury trial in the colonial era, it has not recognized the contribution of abolitionism to our modern understanding of the jury.

Emblematic of the Court's approach is Duncan v. Louisiana, in which the Court held that the Sixth Amendment right to trial by jury applies to the states via the Fourteenth Amendment's Due Process Clause. ${ }^{17}$ Duncan focused exclusively on the jury's role in the colonial era. The Court noted that the revolutionary generation hated unchecked federal or state power as well as corrupt colonial judges whose allegiance lay with the Crown. ${ }^{18}$ Their safeguard was the jury, the only institution that provided for "community participation in the determination of guilt or innocence." 19

Duncan's choice of history is significant. The absence of attention to the Fourteenth Amendment's historical context stands out, given that Duncan was an incorporation case. Similarly absent is any reference to the abolitionists, who were not only the intellectual forebears of the Reconstruction legislatures, but who also, as we shall see, had substantial experience with distant authority overriding community sentiment. In this Part, I explore the way in which abolitionist experience with the fugitive slave laws reinforced the colonial understanding of the jury as the People's last check against oppressive government and arbitrary official power. ${ }^{20}$

\section{A. The Centrality of the Jury to Abolitionist Thought}

The federal fugitive slave laws ensured that "[w]hether they liked it or not, Northerners were part of a political compact that provided for the rendition of fugitive slaves." 21 Part of the nineteenth-century abolitionist struggle was a response to that political reality. Many abolitionists sought to interfere with the implementation of the fugitive slave laws, and all sought to protect free blacks from being kidnapped and falsely claimed as fugitives. Juries became central to both of those efforts.

The Fugitive Slave Clause of the Constitution, passed with virtually no debate, stated:

17. 391 U.S. 145 (1968).

18. Id. at 156 ("Those who wrote our constitutions knew from history and experience that it was necessary to protect against unfounded criminal charges brought to eliminate enemies and against judges too responsive to the voice of higher authority.").

19. Id.

20. The abolitionists' faith in juries was itself a legacy of the colonial era, when the commitment to the jury had been absolute. See AMAR, supra note 13, at 96 ("If we seek a paradigmatic image underlying the original Bill of Rights, we cannot go far wrong in picking the jury.").

21. Paul Finkelman, An Imperfect Union: Slavery, Federalism and Comity 8 (2000) 
No Person held to Service or Labour in one State, under the Laws thereof, escaping into another, shall, in Consequence of any Law or Regulation therein, be discharged from such Service or Labour, but shall be delivered up on Claim of the Party to whom such Service or Labour may be due. ${ }^{22}$

As the text makes clear, while the Clause gave a slaveowner the right to have his property "delivered up," the law was not self-executing. Among other things, it did not establish the procedure for determining whether a person was, in fact, "held to Service or Labour in one State." Almost immediately after the Constitution's ratification, Virginia and Pennsylvania had a dispute over whether a particular black man was free or a slave, and it quickly became apparent that federal legislation would be necessary to implement the Fugitive Slave Clause. ${ }^{23}$

In 1793, Congress passed the Fugitive Slave Act, which empowered a person claiming he owned an alleged fugitive to "seize or arrest such fugitive," and "take him or her before any judge of the circuit or district courts of the United States." 24 Once in court, the person claiming the alleged fugitive had to provide "proof to the satisfaction of such judge or magistrate, either by oral testimony or affidavit," that the claimed person was in fact a slave. ${ }^{25}$ If such proof was provided, the judge or magistrate had to issue a warrant allowing the claimant to recover the alleged fugitive. ${ }^{26}$ Significantly, the alleged fugitive did not have the ability to contest the allegation in court. During debates over the Fugitive Slave Act, Southerners had defeated abolitionist attempts to allow the alleged fugitive to prove that he had been born free or emancipated. ${ }^{27}$

Abolitionists' dissatisfaction with these procedures led them to fight for state laws that would protect free blacks from kidnapping and make it more difficult for slaveowners to recover those who were, in fact, fugitive slaves. These laws varied from state to state, but a consistent theme among abolitionists was the desire to obtain jury trials on the question of whether the alleged fugitive was in fact a fugitive or was instead a free man or

22. U.S. CONST. art. IV, $\S 2$, cl. 3. For reviews of the sparse legislative history of the Clause, see Paul Finkelman, Slavery and the Founders: RaCe AND Liberty in the Age of JefFerson 82-83 (2001); and ThOMAS D. Morris, Free Men All: The Personal LiBerty LAWS OF THE NORTH, 1780-1861, at 16-19 (The Lawbook Exchange, Ltd. 2001) (1974).

23. See FinKelman, supra note 22, at 83-89.

24. Fugitive Slave Act of 1793, ch. 7, § 3, 1 Stat. 302, 302-03 (repealed 1864).

25. Id., 1 Stat. at 303-04.

26. Id., 1 Stat. at 304-05.

27. FinKELMAN, supra note 22 , at 97 . This was not the only Southern victory in drafting the law. As Finkelman concludes, "The law that emerged from these debates ultimately offered little protection for the North and at the same time satisfied most of the slave owners in Congress." Id. at 93 . 
woman. ${ }^{28}$ Many abolitionists were confident that Northern juries would express their antislavery sentiment by consistently finding that the alleged fugitive was actually free. Henry B. Stanton spoke for them when he asserted at an American Anti-Slavery Society meeting in 1839:

"Give the panting fugitive this inestimable right [to a jury trial] in every northern State, and he is safe,-for, where can you find twelve impartial men among us who will decide on their oaths, that a man has not a better right to himself than another has to him ... ??"29

While Stanton spoke for those abolitionists who argued that juries should nullify in cases where the evidence suggested that the alleged fugitive was a slave, other abolitionists recognized an obligation to return such fugitives. These other abolitionists nonetheless considered the jury trial essential to determining the factual question of whether a person was a slave or free. A Pennsylvania Anti-Slavery Society Convention passed the following resolution in 1837 :

Resolved, That whatever difference of opinion may exist in respect to the degree and kind of obligation resting on the people of the free states, under the Federal Constitution, to return fugitive slaves to their masters, there is no obligation imposed on the sovereign states, to surrender the liberties of any person without trial by jury.

The Court reviewed a state attempt to regulate the fugitive slave process in Prigg v. Pennsylvania and upheld the constitutionality of the Fugitive Slave Act, striking down a Pennsylvania law as interfering with a slaveowner's right of recapture under federal law. ${ }^{31}$ But because the Prigg Court was fractured (Justice Story's opinion "for the Court" is the opinion of three Justices), and its reasoning less than obvious, abolitionists opposed to the summary federal fugitive slave procedures were still able to agitate for state protection of alleged fugitives. After Prigg, the abolitionists'

28. In Pennsylvania, for example, abolitionists fought for jury trial but were unsuccessful. MORRIS, supra note 22, at 49,51. The Pennsylvania law did include other protections important to abolitionists, such as the requirement that the claimant seek a warrant before arresting the fugitive, and a mandatory time period in which the alleged slave could bring evidence to refute the claim. See id. at 51-52. In New York, by contrast, abolitionists won the right to a jury trial for alleged fugitives. Id. at 57 .

29. Id. at 73 (quoting SIXTH ANNUAL REPORT OF THE EXECUTIVE COMMITTEE OF THE AMERICAN ANTI-SLAVERY SOCIETY 15-16 (New York, 1839)).

30. Id at 74 (quoting PROCEEDINGS OF THE PENNSYLVANIA CONVENTION, ASSEMBLED To ORganize a STATE ANTI-SLAVERY SOCIETY, AT HARRISBURG, ON THE 31ST OF JANUARY AND 1ST, 2D, 3D OF FEBRUARY 1837, at 57 (Philadelphia, 1837)).

31. 41 U.S. (16 Pet.) 539 (1842). 
principal approach was to withdraw any state support for slaveowners seeking to enforce the Fugitive Slave Act and capture blacks, making both the kidnapping of free blacks and the recovery of slaves more difficult. ${ }^{32}$

Southerners had never been entirely happy with the Fugitive Slave Act of 1793 themselves. Though it allowed slave masters and slave catchers to bring claims for the return of alleged fugitives in Northern courts, it did not provide them with federal aid. Accordingly, the cost of traveling, bringing suit, and paying lawyers could exceed the value of the slave. ${ }^{33}$ Moreover, even significant penalties for interfering with recovery were insufficient to deter abolitionist opposition to recovery efforts. ${ }^{34}$ These deficiencies, combined with the abolitionists' attempts to thwart enforcement of the law, caused Southerners to push for federal revision of the 1793 Act. Once again, this debate would highlight the centrality of the jury to abolitionist ideology.

\section{B. The Jury Trial and the Fugitive Slave Act of 1850}

South Carolina Senator Arthur P. Butler first introduced a bill to amend the Fugitive Slave Act of 1793 in 1848, but debate did not begin in earnest until $1850 .{ }^{35}$ Early in the congressional debate, Senator William L. Dayton of New Jersey introduced an amendment proposing jury trials for alleged fugitives. The amendment read:

That if the fugitive shall deny that he owes service to the claimant under the laws of the State where he was held, and after being duly cautioned as to the solemnities and consequences of an oath, shall swear to the same, the commissioner or judge shall forthwith summon a jury of twelve men to try the right of the claimant, who shall be sworn to try the cause according to evidence, and the commissioner or judge shall preside at the trial and determine the competency of the proof. ${ }^{36}$

The response from the bill's opponents, particularly Southern senators, was quick and furious. Senator James Murray Mason, a Virginia Democrat, complained that the jury trial provision was "a proposition brought up by the Abolitionist Societies and the Liberty people," and said its adoption

32. Massachusetts and Pennsylvania, for example, prohibited state officers from aiding in the arrest or detention of alleged fugitives, and prohibited the use of state facilities to hold fugitives pending their federal hearing. MORRIS, supra note 22, at 114, 118.

33. See Paul Finkelman, Legal Ethics and Fugitive Slaves: The Anthony Burns Case, Judge Loring, and Abolitionist Attorneys, 17 CARDOZO L. REV. 1793, 1797 (1996).

34. Anyone interfering with recovery was subject to a fine of $\$ 500$. Fugitive Slave Act of 1793 , ch. 7, $\S 4,1$ Stat. 302, 305 (repealed 1864).

35. MORRIS, supra note 22, at 131-32.

36. CONG. GlOBE, 31st Cong., 1st Sess. app. at 1583 (1850). 
would constitute notice of the federal government's refusal "to execute the provisions of the Constitution of the United States. ${ }^{" 37}$ According to Mason, "If you pass a law which shall require a trial by jury, not one man in twenty whose slave escapes will incur the risks or expense of going after the fugitive." 38 This was so, said Mason, because of the expense and delay that a jury trial would entail, particularly in terms of gathering evidence. ${ }^{39}$ Mason complained that it was already difficult enough for slaveowners to recover their property:

[I]t has become a part of the history of the country, that, when a slave once escapes and gets within the limits of the free States ... you may as well go down into the sea, and endeavor to recover from his native element a fish which had escaped from you, as expect to recover such fugitive ... ${ }^{40}$

Dayton questioned whether delay was the true basis for Mason's opposition to the jury trial provision, arguing that the adjudication of whether a person was a slave or free "is tried on precisely the same evidence before a jury as before a single commissioner." ${ }^{41}$ Not only would the jury cause no more delay than a commissioner, argued Dayton, but juries were also excellent triers of fact. He argued, "Sir, there is no tribunal upon which you can rest your rights more safely than you can upon twelve citizens, sworn then and there at the time and in the place to render a verdict according to the law and evidence." also endorsed the jury trial, arguing that it was not only wise, but also constitutionally mandated. ${ }^{43}$ Referring to the Seventh Amendment requirement that the right to jury trial attaches to disputes involving more than twenty dollars, Chase concluded that "[i]f the most ordinary controversy involving a contested claim to twenty dollars must be decided

37. Id. app. at 1584 (statement of Sen. Mason).

38. $I d$.

39. Id.

40. Id. app. at 1583. Mason outlined the difficulties that the slave states faced in recovering fugitives:

Every difficulty is thrown in the way by the population to avoid discovery of where he is, and after this discovery is made, every difficulty is thrown in the way of executing process upon him. And if you should succeed so far as to execute the process, then every difficulty is thrown in the way by armed mobs to prevent the fugitive being carried before the proper officer to take cognizance of the case. And, if you should perchance succeed in doing this, and an adjudication should be made, I do not know of an instance, within recent years, where the fugitive was not rescued by violence from the hands of the officer by an armed mob, and the parties claiming him put in peril of Id. their lives.

41. Id. app. at 1584 (statement of Sen. Dayton).

42. $I d$.

43. Id. app. at 1587 (statement of Sen. Chase). 
by a jury, surely a controversy which involves the right of man to his liberty should have a similar trial., ${ }^{, 4}$

Jefferson Davis, the Mississippi Democrat and future president of the Confederacy, responded to these arguments by suggesting that if there were to be juries, they should be drawn from the slave state community from which the alleged fugitive was said to have fled: "A wanderer is found in a village or city, and a claim is made that he is a fugitive slave. Are the inhabitants of that village or city the best judges whether he is a slave, or the inhabitants of the place whence he is said to have fled?"45

Davis concluded that the reluctance to hold the jury trial in the location most likely to have the relevant facts was evidence of suspect motives on the part of those supporting the jury amendment. According to Davis, what many in the North held was "not a commendable respect for the trial by jury, but a prejudice against the right recognized by the Constitution to own slave property." 46

Northern senators responded to these arguments by arguing that "[i]t must always be a question whether such a person be your slave, or whether he be our freeman., ${ }^{, 7}$ The second question - whether the fugitive was a freeman - still needed to be answered by a jury in the free state. ${ }^{48}$

The final element of the congressional jury debate concerned the question of community sentiment and the legitimacy of law. Senator Robert Charles Winthrop of Massachusetts initiated this debate by arguing that providing for juries would actually increase the likelihood that fugitives would be returned, because it would enhance the legitimacy of the law in the eyes of the North. ${ }^{49}$ Winthrop's suggestion brought a strong rebuke

44. Id.

45. Id. app. at 1588 (statement of Sen. Davis).

46. $I d$.

47. Id. app. at 1585 (statement of Sen. Winthrop).

48. See id. According to Winthrop,

Now, whether he be your slave might be a question very proper to be tried by a jury of the vicinage, and to be decided on the spot where the professed owner resides; but whether he be our freeman would seem to be a question which, upon the very same principle, should be tried where he is seized, and where the immediate liberty which he Id. enjoys is about to be taken away from him.

49. Id. Winthrop explained the link between legitimacy and enforcement as follows: [A]ll laws depend in no small degree for their efficiency upon the public sentiment of the State or the community in which they are to be executed. If there be a strong sense of the injustice and oppressiveness of any particular provision, whether of this law or of any other, there will alway[s] be more or less of opposition to its execution. On the other hand, if provisions should be inserted in this bill like [the jury provisions], which cannot but accord with the sense of justice, and the strong preconceived opinions of right, of the communities in which this law is to have its main operation and effect, I believe it would in most cases be faithfully carried out, and that more fugitives from labor would be returned to their masters under its operation than have been returned within the last half century.

Id. 
from Davis, who suggested that Winthrop's statement regarding Northern opposition to the fugitive slave law was an admission that Northern juries could not be trusted to enforce it. According to Davis, "If it is admitted that the law cannot be executed because of the opposition to it, growing out of the popular feeling, the jury reflecting that popular feeling will decide against it, in accordance with preconceived opinions." 50 Davis also questioned whether lawmakers should allow lawless community sentiment to govern their actions. ${ }^{51}$ Winthrop responded by arguing that he had been misunderstood. He said that lawmakers should not be guided by the fact that many Northerners opposed slavery, but they should consider the fact that many were committed to the jury trial right. ${ }^{52}$

So concluded the debate on Dayton's jury trial amendment. After closing debate, Congress voted to reject the amendment. ${ }^{53}$ When the Fugitive Slave Act of 1850 was passed, it contained no jury provisions. ${ }^{54}$ Nor was this the only procedural protection missing. On the whole, the Act envisioned hearings as summary affairs. ${ }^{55}$ To recover the alleged fugitive, the slaveowner had only to produce an affidavit, signed by an officer of a Southern court, that described the alleged fugitive and said he was owned by the claimant. ${ }^{56}$ The black man could not testify on his own behalf, ${ }^{57}$ was not provided an attorney, and was not entitled to a public hearing. ${ }^{58}$ There was no right to appeal the commissioner's decision. ${ }^{59}$ Finally, the commissioner received a five-dollar fee if he decided that the black man was free, but ten dollars if he found he was a slave. ${ }^{60}$ According to Paul Finkelman, "[T]he whole tenor of the law was corrupt. It penalized

50. Id. app. at 1588 (statement of Sen. Davis).

51. See id.

52. See id. (statement of Sen. Winthrop).

53. Id. app. at 1589.

54. See Fugitive Slave Act of 1850, ch. 60, 9 Stat. 462 (repealed 1864).

55. See id. $\S 6,9$ Stat. at 463.

56. See id.

57. Id. My colleague Jim Oldham has pointed out that the preclusion of fugitive testimony appears more shocking to twenty-first-century eyes than to nineteenth-century ones, given the common law party-witness rule that prohibited the defendant from testifying under oath. The rule held in England until 1898, but was lifted in most American states a few decades earlier. JOHN LANGBEIN, THE ORIGINS OF ADVERSARY CRIMINAL TRIAL 52-53 (2003). For more detail on the history of the party-witness rule in the United States, see George Fisher, The Jury's Rise as Lie Detector, 107 YALE L.J. 575, 656-97 (1997). For the history of the rule in England, see James Oldham, Truth-Telling in the Eighteenth-Century English Courtroom, 12 LAW \& HIST. REV. 95, 107-13 (1994). Nonetheless, it is worth noting that in the fugitive slave context more was at stake than the common law rule, for Senator Dayton and his supporters envisioned that fugitives would be permitted to testify under the proposed jury amendment. Under the Dayton amendment, "if the fugitive shall deny that he owes service to the claimant... [and] shall swear to the same," the right to a jury trial was triggered. CONG. GLOBE, 31st Cong., 1st Sess. app. at 1583 (1850).

58. See Fugitive Slave Act of $1850 \S 6,9$ Stat. at 463; see also Finkelman, supra note 33, at 1801.

59. Fugitive Slave Act of $1850 \S 6,9$ Stat. at 463-64.

60. Id. $\S 8,9$ Stat. at 464 . 
opponents of slavery, mocked due process, undermined the independence of those authorized to enforce the law, and worst of all, made Northerners into slave catchers." ${ }^{61}$ The abolitionists, defeated by the Supreme Court, had now lost in Congress. ${ }^{62}$

The Fugitive Slave Act of 1850 provoked outrage in the abolitionist community. The response demonstrated the centrality of juries to abolitionist philosophy, for the absence of the jury trial was a constant refrain. Senator Charles Sumner of Massachusetts, speaking at Boston's Faneuil Hall, argued that "[i]n denying the Trial by Jury, [the Fugitive Slave Act] is three times unconstitutional. ${ }^{, 63}$ According to Sumner, the Act contravened the Search and Seizure Clause of the Fourth Amendment, the Due Process Clause of the Fifth Amendment, and the jury trial provisions of the Seventh Amendment. ${ }^{64}$

Josiah Quincy, a former Massachusetts congressman and president of Harvard University, asked how alleged fugitives could be seized without juries when a claim "of ownership for a cow, an ox, or a horse, or an acre of land" all required a jury trial. ${ }^{65}$ According to Quincy, if the delegates to the Massachusetts Constitutional Convention had been aware that the Constitution would later be interpreted to allow the Fugitive Slave Act, "it is impossible, in my judgment, that the constitution of the United States could have received the sanction of one-tenth part of the people of Massachusetts." 66 There was only one way, said Quincy, to satisfy the abolitionists' complaints: allow for a Massachussets jury to judge fugitive slave cases. ${ }^{67}$ Former Massachusetts congressman Charles Allen marshaled his rhetorical talents against the Act in similar fashion. ${ }^{68}$

61. Finkelman, supra note 33, at 1801.

62. See, e.g., MORRIS, supra note 22, at 146-47 ("Every effort by northerners to include some security for free blacks, particularly the trial by jury and habeas corpus, was defeated by a coalition of southerners and some northern Democrats. ... Every guarantee, every security in the new law was for the 'rights' of slave owners.")

63. Mr. Sumner's Speech at Faneuil Hall, Nov. 6, 1850, EMANCIPATOR \& RePUbliCAN, Nov. 14,1850 , at 1 .

64. Sumner believed that these three provisions worked together: "By this triple cord did the framers of the Constitution secure the Trial by Jury in every question of Human Freedom." Id.

65. Faneuil Hall Mass Meeting on the Fugitive Slave Bill!!, EMANCIPATOR \& REPUBLICAN, Oct. 17, 1850, at 3 (reprinting Letter from Sen. Josiah Quicy to J. Ingersoll Bowditch, Esq. (Oct. 14, 1850))

66. Id.

67. Id.

68. After a lengthy and rousing denunciation of the Fugitive Slave Act, the slave power, and Daniel Webster (who had supported the Act), Allen addressed the law's constitutional underpinnings. He told the audience,

You will be told that the Constitution of the United States requires this law, that the fugitive must be delivered up; that in a former age the Constitution was made, when the evils of slavery were not appreciated as they now are, and that the Constitution requires, that they from whom service or labor is due, shall be given up. 
Following the lead of men like Sumner, Quincy, and Allen, abolitionist conventions condemned the absence of a jury trial provision in the law. ${ }^{69}$ The abolitionist press condemned the first juryless proceeding in which an alleged fugitive slave was returned to a slaveowner: "It is the first arrest under the new law. The poor slave was not allowed to open his mouth. The proceedings were summary and quick, and a freed man once more became a slave. There is a cold hearted cruelty about this proceeding that chills the blood." $" 70$

In addition to opposing the absence of a jury trial provision in the Fugitive Slave Act, many abolitionists objected to the Act's encroachment on states' rights. The pre-Civil War experience with fugitive slaves led to staunch localism within the abolitionist movement. ${ }^{71}$ The Emancipator \& Republican reminded its readers that "[t]he excitement of the Northern people is not the offspring of an exclusive sympathy with the black man." 72 While concern for slaves was important, said the paper, the Fugitive Slave Act also was objectionable because it "encroaches upon state sovereignty - it establishes summary processes of trial and conviction unknown to the common law [and] it insults the people of the free States, by commanding them, whenever it may be required of them, to become catchpoles to the slave-hunter." ${ }^{, 73}$ Representative Joshua Giddings of Ohio spoke for many abolitionists when he declared,

If there be any one feature in the Constitution, which the whole history of its adoption has made plain, it is, that Slavery is a State institution over which Congress has no legitimate powers to interfere. We, sir, of the North, will not be constrained, even by your fugitive laws, to interfere with it. The slavery of Virginia belongs to her. ${ }^{74}$

The Emancipator \& Republican echoed Giddings's sentiment in an editorial published the same day. The newspaper declared, "Resolved, That among the powers delegated to the general Government by the Constitution, that of legislating upon the subject of fugitives from service is

Speech of Hon. Charles Allen at the City Hall in Worcester, Oct. 5, 1850, EMANCIPATOR \& REPUBLICAN, Oct. 17, 1850, at 1. But, Allen concluded, "nowhere is it declared in the Constitution that any man shall lose his liberty without a trial by jury." Id.

69. See, e.g., The Fugitive Slave Law, EMANCIPATOR \& REPUBLICAN, Oct. 27, 1850, at 3 (reporting on petitions from Syracuse and Brockport, New York, and from Allegheny, Pennsylvania).

70. Slave Catching in New York, EMANCIPATOR \& REPUBLICAN, Oct. 3, 1850, at 3 .

71. The abolitionists were not the first to make the connection between juries and localism; the Constitution's Framers also linked the two. See AMAR, supra note 13, at 88-89.

72. The Agitation at the North, EMANCIPATOR \& REPUBLICAN, Nov. 7, 1850, at 1.

73. Id.

74. Speech of Hon. Joshua R. Giddings, EMANCIPATOR \& RePUBLICAN, Dec. 26, 1850, at 1. 
not to be found." 75 According to the paper, the extension of national power inherent in the Fugitive Slave Act had grave consequences:

Vain will be all the safeguards thrown so jealously around the rights of the states, and of individuals, by the vigilance of our forefathers, if an act of Congress, resting upon a single clause in the national compact, and supported in part by only a single decision of the majority of the Judges of the Supreme Court, has sufficient potency to trample them all under foot. If state sovereignty is worth anything, at any time, it should be when the rights and liberties of its subjects are thus imminently assailed. ${ }^{76}$

For many Northerners, the encroachment on states' rights and local prerogative was so great that they would have preferred no union to a union of that sort. According to the Emancipator \& Republican,

[S]ooner than have the streets of our cities made a hunting ground for the slaver, and the villages of our Northern hills laid open to the trader in human beings, that he may tear from them the men and women who have made themselves homes there - the South might begin its secession to-morrow. In a Union for such robbery we will have no part. ${ }^{77}$

The fight over the fugitive slave laws was, for many in the North, simply one battle in the larger war against the encroaching slave power. Abolitionists felt revulsion as they watched fugitives returned in juryless proceedings - revulsion at the brutality of the slave system and the encroachment of Southern and federal authority on their local prerogative. For some, this disgust manifested itself in a willingness to defy the Fugitive Slave Act of 1850. They had tried to vindicate local values through legal procedures such as the jury trial, but their attempts were rejected - first by the Court, and then by Congress. In response, increasing numbers pledged to oppose the Fugitive Slave Act through other means. For example, a mass meeting at Faneuil Hall ended with the adoption of a resolution that "the citizens of Boston in Faneuil Hall assembled, law or no law, constitution or no constitution, pledge themselves to protect at all hazards fugitive slaves who have taken shelter in their city." 78

75. The Fugitive Slave Law, EMANCIPATOR \& REPUBLICAN, Dec. 26, 1850, at 2.

76. Id.; see Letter from William Jay, EMANCIPATOR \& REPUBLICAN, Oct. 27, 1850, at 1; The Manstealing Law, EMANCIPATOR \& REPUBLICAN, Oct. 27, 1850, at 2; see also Anthony J. Sebok, Note, Judging the Fugitive Slave Acts, 100 YALE L.J. 1835, 1847 (1991) (arguing that the Fugitive Slave Act of 1850 was unconstitutional because it violated the principle of comity by forcing free states to adopt the legal premises of slave states).

77. The Christian View, EMANCIPATOR \& REPUBLICAN, Oct. 27, 1850, at 3.

78. Faneuil Hall Mass Meeting on the Fugitive Slave Bill!!, supra note 65. 
Those who met at Faneuil Hall exemplified the portion of the abolitionist community that was willing to break the law openly and accept the consequences. At the same time that they and other abolitionists defied federal law, however, they attempted to use local law to validate this defiance. For this, juries would be important. Juries could no longer declare alleged fugitives free, but they could free those Northerners who protected fugitives and those fugitives who defended themselves. ${ }^{79}$ William Spooner stated his conviction that jurors would understand that the law of God opposed slavery, even if the federal government did not. To a responsive audience, Spooner made the following appeal:

Gentlemen, whatever you may think, I say this cruel law will not be obeyed. It contravenes men's convictions of obligation to a higher than any human authority. ... The law will be resisted, and if the fugitive resists, and if he slay the slave hunter, or even the marshal, and if he therefor be brought before a jury of Massachusetts men, that jury will not convict him. ${ }^{80}$

Nullification appeals like this proved an attractive way for abolitionists to take some control over the matter of fugitive slaves. But as resistance turned to war, and the North's views on abolition finally prevailed, the ability of all-white Southern juries to nullify also became the basis for a new set of struggles over the role of the jury and race.

\section{RECONSTRUCTION AND THE JURY}

As we have seen, the abolitionists' experience with fugitive slaves confirmed the colonial belief that the jury was a bulwark of liberty. It would not be long, however, before this view would be challenged. Almost immediately after the Civil War, the South began a practice that would continue for many decades: All-white juries punished black defendants particularly harshly, while simultaneously refusing to punish violence by

79. Even after 1850, four states-Vermont, Massachusetts, Michigan, and Wisconsincontinued to attempt to protect blacks by providing for jury trials in fugitive slave cases. Stanley W. CAMPBell, The Slave CATChERs: ENFORCEMENT OF THE Fugitive SLAVE LAW, 1850-1860, at 180 (1968); see also MORRIS, supra note 22, at 168 (describing state responses to the Fugitive Slave Act of 1850). For a summary of Vermont's law, which was similar to the laws of the other three states, see CAMPBELL, supra, at 180. Northern states justified the laws on the ground that they applied to free men only, and as such were consistent with the Constitution.

80. Speech of William Spooner, on Taking the Chair in Faneuil Hall, Nov. 6th, 1850, EMANCIPATOR \& REPUBLICAN, Nov. 14, 1850, at 4. Spooner's higher law appeal was used in practice. See, e.g., Robert M. COVER, Justice ACCuSED: ANTISLAVERY AND the Judicial PROCESS 212 (1975) ("[T]he presence of a jury in the criminal and civil actions brought under the Fugitive Slave Act's enforcement provisions precipitated direct appeals to conscience and to the responsibility of the jurors to God's law. These appeals required explicit consideration of the place of morality in the jury's deliberations."). 
whites, including Ku Klux Klan members, against blacks and Republicans. The Reconstruction Republicans' response to this crisis is revealing. If Southern juries were now nullifying, just as some abolitionists had encouraged Northern juries to do during abolition, one approach would have been to introduce additional juryless summary proceedings like those that had marked the Fugitive Slave Act. But although many Reconstruction Republicans were instrumentalists, I have found no evidence of this response. It certainly seems possible that ideology-specifically, the longstanding commitment to juries that had been enshrined during abolitionism - played a restraining influence and made it unthinkable to attempt to limit the power of even overtly hostile juries. ${ }^{81}$ Regardless of the reason, the abolitionists' heirs responded to what they perceived as a nullifying Southern criminal justice system by trying to ensure blacks' participation in the legal process. This meant eliminating the prohibition against blacks serving as witnesses, providing for federal court enforcement in some criminal cases, and, ultimately and most significantly, attempting to ensure that blacks sat on criminal juries.

\section{A. The Unlikely Notion That Blacks Would Serve as Jurors}

Putting blacks on juries was a radical idea. It is believed that 1860 was the first year in which African Americans served on juries, in either the North or the South. ${ }^{82}$ In Congress, the subject of blacks on juries first arose during debates over legislation that would allow blacks to serve as witnesses against whites. ${ }^{83}$ Most remarkable about those debates were the lengths to which Republicans went to demonstrate that the proposed laws regarding blacks as witnesses would not put blacks on juries. ${ }^{84}$

81. Of course, this is not the only possible explanation. Clearly the Sixth Amendment's jury trial guarantee meant that any serious intrusion into the jury's prerogative would have required a constitutional amendment. While the Thirteenth, Fourteenth, and Fifteenth Amendments demonstrate that some Reconstruction legislators were willing to contemplate radical revisions to the Founding Fathers' original structure, I have found no proposals to restrict the Sixth Amendment jury trial right.

82. Alschuler \& Deiss, supra note 12 , at 884 .

83. In many states, North and South, an African American, slave or free, could not serve as a witness against a white person. As the Ohio Supreme Court noted,

No matter how pure the character, yet, if the color is not right, the man cannot testify.

The truth shall not be received from a black man, to settle a controversy where a white man is a party. Let a man be Christian or infidel; let him be Turk, Jew, or Mahometan; let him be of good character or bad; even let him be sunk to the lowest depths of degradation; he may be witness in our Courts if he is not black. Jordan v. Smith, 14 Ohio 199, 201 (1846).

84. This is not to say that no blacks ever served as jurors in the South during the years shortly after the war. The black press eagerly covered news of black jury experiences, and it is possible to find occasional reports of service. The New Orleans Tribune, for example, reprinted a story from the Houston Telegraph in which the correspondent reported that "[t]he experiment of negro jurors ... has been tried in this country, and I am glad to say that, although humiliating, it has 
In 1864, Congress discussed a proposed bill to allow blacks to carry U.S. mail and testify in federal courts in order to provide evidence in the case of mail robbery. ${ }^{85}$ Indiana Democrat Thomas Hendricks opposed the bill on the ground that if blacks were allowed as witnesses they would therefore be qualified to serve as jurors. Iowa Republican James Harlan responded that no such radical result was contemplated or required: "[T]he Senator argues that if you permit a colored man to testify you ought to permit him to sit as a juryman. How so?" ${ }^{96}$ According to Harlan, there were many categories of individuals who could serve as witnesses but not as jurors:

I believe you allow females to testify before the courts. Does it follow as a logical necessity that women must be authorized to sit as jurymen? You allow minor children to testify before the courts. Does it follow as a logical sequence that every child who is competent to testify as a witness ought to be authorized to sit as a juryman, and aid in trying cases? ${ }^{87}$

Two years later, in 1866, Congress debated the Freedmen's Bureau Bill and the Civil Rights Bill. The dispute about whether the legislation would lead to blacks serving on juries was replayed. Illinois Senator Lyman Trumbull, Chairman of the Judiciary Committee, argued that the Freedmen's Bureau Bill and Civil Rights Bill were necessary in part because they would allow Negroes to testify, which would help ensure that violence against Negroes did not go unpunished. ${ }^{88}$ Iowa Representative

been attended with no serious results." Colored Jurors in Texas, NEW ORLEANS TRIB., July 4, 1867 , at 1 . Needless to say, the Telegraph was a paper "whose sympathies are not with the newly enfranchised citizen." Id.

The New Orleans Tribune had a very different history. Started by a group of free blacks in New Orleans during the Civil War, it was edited by Jean-Charles Houzeau, a white Belgian who passed for black. David C. Rankin, Introduction to JEAN-CHARLES HOUZEAU, My PASSAGE AT THE NEW ORLEANS TRIBUNE: A MeMOIR OF THE Civil WAR ERA 1 (David C. Rankin ed. \& Gerard F. Denault trans., La. State Univ. Press 1984) (1870). Throughout the remainder of this Essay, I rely on the writings of the black press, an essential source for Reconstruction history. See, e.g., David Wycoff, Legislation Especially for the Negro? The Black Press Responds to Early Supreme Court Civil Rights Decisions, 3 YAle J.L. \& LiBERATIOn 38, 39 (1992).

85. See CONG. GLOBE, 38th Cong., 1st Sess. 837 (1864).

86. Id. at 840 (statement of Sen. Harlan).

87. Id.

88. CONG. GloBe, 39th Cong., 1st Sess. 941 (1866) (statement of Sen. Trumbull). Black Southerners also linked the right to testify with the right to be free from violence. In an open appeal to the Kentucky General Assembly, the State Convention of Colored Men argued that "[w]e believe that much good will accrue, both to the white and the black people, when this right of testimony is given to our people in all cases; and thus society will be more effectually protected from crime of every character than it is at present." PROCEEDINGS OF THE STATE Convention of Colored Men, Held at Lexington, Kentucky, in the A.M.E. Church, NOVEMBER 26TH, 27TH AND 28TH, 1867, at 9 (1867). Without the right to testify, argued Kentucky blacks, 
James F. Wilson agreed with Trumbull's assessment of the need for the Civil Rights Bill. He emphasized that allowing Negroes to serve as witnesses would not confer upon them the right to serve as jurors. ${ }^{89}$ These arguments did not persuade President Johnson. The Fourteenth Amendment had not yet been enacted, and Johnson vetoed the Civil Rights Bill as an unconstitutional exercise of congressional power, concluding that "[i]f Congress can declare by law ... who shall testify ... then Congress can by law also declare who, without regard to color or race, shall have the right to sit as a juror or as a judge, to hold any office, and, finally, to vote." 90

These early debates are especially interesting for what was not argued. Nobody disputed that it would be inappropriate for Congress to grant blacks the right to serve on juries. The debate turned instead on whether the bill made sufficiently clear that it was not conferring such a right. Representative Columbus Delano of Ohio, an opponent of the bill, made this clear in a colloquy with Wilson: "I presume that the gentleman himself will shrink from the idea of conferring upon this race now, at this particular moment, the right of being jurors, or from so wording this bill as to leave it a serious question and render it debatable hereafter in the courts or elsewhere." ${ }^{.91}$ Wilson did not question Delano's presumption.

Congress first directly addressed the question of providing blacks the right to serve on juries in 1867, while debating a bill that would have allowed blacks to hold office and serve as jurors in the District of Columbia. ${ }^{92}$ Stripped of the constitutionality arguments that had marked consideration of the Civil Rights Bill, debate over the jury legislation required the bill's supporters and opponents to squarely face the merits of allowing black participation in the heart of the criminal justice system. The bill's supporters made clear that the right to serve as jurors was, for them, simply part of the natural evolution of rights for the freedmen. ${ }^{93}$ Its

we can be despoiled of our property, our females may be outraged, our school teachers shot down at their desks, and our ministers murdered in their pulpits, by any person lawless enough to do so; and the sad history of the past few years must convince you that many men, thus lawless, live in Kentucky, and we have no remedy in the courts, if the only witnesses happen to have African blood in their veins, no matter how truthful or intelligent they may be.

Id. (statement of Business Committee).

89. CONG. GloBe, 39th Cong., 1st Sess. app. at 156-57 (1866) (statement of Rep. Wilson).

90. Id. at 1680 (statement of Pres. Johnson).

91. Id. app. at 157 (statement of Rep. Delano).

92. See CONG. GloBE, 40th Cong., 2d Sess. 38-39, 49-51 (1867).

93. Indeed, some supporters believed that the bill did not go far enough. Kansas Senator Samuel Pomeroy noted that while he supported the bill, he hoped that Congress would be able to achieve equal rights for black Americans in one fell swoop, and not be forced to engage in piecemeal legislation:

First, by one bill we get the colored man into a car, and then we give him the right of suffrage, and we do a little at a time. This simply relieves his disabilities so far as relates to being a juror and holding office in this District, but it does not strike out the 
opponents openly exposed their prejudices, basing their argument on the purported inability of blacks to try cases fairly and accurately. According to Senator Reverdy Johnson of Maryland, "[T] he question for the Senate to decide is whether we are willing to have ourselves tried by a jury of black men for the most part just emerged from slavery, without the capacity absolutely necessary to a faithful and intelligent discharge of that duty." ${ }^{\circ 4}$ Johnson argued that whites should not allow themselves to be subjected to a judgment "pronounced by twelve ignorant black men." 95

Echoing the arguments they had made against the laws allowing blacks to serve as witnesses, the bill's opponents stressed that Congress was on a slippery slope, one that would eventually lead to black participation in all aspects of the justice system. Senator Hendricks pointed out that "this bill proposes not only that negroes shall be allowed to hold office ... but that they shall be allowed to sit upon the juries. Of course it will follow that they may be judges. The spectacle will then be presented of negro courts to try cases." ${ }^{96}$ Hendricks objected, saying that black participation "is not in accordance with my taste, and I think not in accordance with the taste of the people I have the honor in part to represent." 97

Once Congress allowed Negroes such access to power, said the bill's opponents, black domination was likely to result, particularly given the large black population of the District. According to Johnson,

The number of the black race in this District is very large and promises to become larger. It may be able to elect out of its own numbers to every office, judicial or otherwise, that is not now to be filled by the Executive with the consent of the Senate. We may give them the authority to elect their magistrates; we may give them the authority to elect their judges; there is nothing to prevent it; and then we should be placed in the condition of having a tribunal to decide upon our rights, civil and criminal, constituted of persons of that race alone.... I am against giving to them a privilege which may be exercised to the detriment of the rest of the public, and which is not at all necessary to the vindication of all of their own rights. ${ }^{98}$

Senator Hendricks echoed Johnson's concern, saying simply, "I am opposed to this policy which subjugates the white race to the colored

code which is in this District. It is not a clean thing. It does not do what ought to be done.

Id. at 39 (statement of Sen. Pomeroy).

94. Id. (statement of Sen. Johnson).

95. Id.

96. $I d$. at 50 (statement of Sen. Hendricks).

97. Id.

98. Id. at 39 (statement of Sen. Johnson). 
race." 99 The bill's opponents' final objection was to the fact that it covered a limited area (the District of Columbia), while the home states of senators would not be covered. Hendricks stated: "Now, how can [Senator Morton] say that a people, fair, honest, and generous, who would repudiate a policy when applied to themselves as being unworthy of them, unjust to them, unsafe to their institutions, would force that same policy upon another people, upon the District of Columbia?" ${ }^{100}$ Despite this opposition, the bill became law in $1869 .^{101}$

At the same time that Congress was debating black participation in the District of Columbia justice system, it was also receiving increasingly urgent reports regarding similar discrimination in the South. In particular, violence against blacks and Republicans was mounting and was going largely unpunished. Over time, this violence would give rise to national debates over blacks as jurors, causing the debates that took place over the District of Columbia bill to play out on an even larger scale.

\section{B. A Campaign of Terror Against Blacks and Republicans}

Defendants convicted of crimes can appeal, occasionally all the way to the Supreme Court. Of course, victims whose cases are not prosecuted, or for whom the prosecution does not result in a conviction, get no appeal. Accordingly, the Supreme Court's jury discrimination decisions all involve cases where all-white juries convict black defendants. ${ }^{102}$ Taken together, these decisions create an incomplete constitutional history of jury discrimination; they lead to the conclusion, endorsed by three members of

\footnotetext{
99. Id. at 50 (statement of Sen. Hendricks).

100. Id.

101. Act of Mar. 18,1869 , ch. 3,16 Stat. 3 .

102. A nonexhaustive chronological list of jury discrimination cases in which black defendants challenged state law or practices before the Supreme Court on the ground that they excluded potential jurors on the basis of race includes the following: Strauder v. West Virginia, 100 U.S. 303 (1880); Virginia v. Rives, 100 U.S. 313 (1880); Neal v. Delaware, 103 U.S. 370 (1881); Bush v. Kentucky, 107 U.S. 110 (1883); Andrews v. Swartz, 156 U.S. 272 (1895); Gibson v. Mississippi, 162 U.S. 565 (1896); Smith v. Mississippi, 162 U.S. 592 (1896); Murray v. Louisiana, 163 U.S. 101 (1896); Williams v. Mississippi, 170 U.S. 213 (1898); Carter v. Texas, 177 U.S. 442 (1900); Rogers v. Alabama, 192 U.S. 226 (1904); Martin v. Texas, 200 U.S. 316 (1906); Thomas v. Texas, 212 U.S. 278 (1909); Norris v. Alabama, 294 U.S. 587 (1935); Hollins v. Oklahoma, 295 U.S. 394 (1935) (per curiam); Hale v. Kentucky, 303 U.S. 613 (1938) (per curiam); Pierre v. Louisiana, 306 U.S. 354 (1939); Smith v. Texas, 311 U.S. 128 (1940); Hill v. Texas, 316 U.S. 400 (1942); Patton v. Mississippi, 332 U.S. 463 (1947); Cassell v. Texas, 339 U.S. 282 (1950); Avery v. Georgia, 345 U.S. 559 (1953); Williams v. Georgia, 349 U.S. 375 (1955); Reece v. Georgia, 350 U.S. 85 (1955); Eubanks v. Louisiana, 356 U.S. 584 (1958); Arnold v. North Carolina, 376 U.S. 773 (1964) (per curiam); Coleman v. Alabama, 377 U.S. 129 (1964); Swain v. Alabama, 380 U.S. 202 (1965); Whitus v. Georgia, 385 U.S. 545 (1967); Jones v. Georgia, 389 U.S. 24 (1967) (per curiam); Sims v. Georgia, 389 U.S. 404 (1967) (per curiam); Alexander v. Louisiana, 405 U.S. 625 (1972); Vasquez v. Hillery, 474 U.S. 254 (1986); and Batson v. Kentucky, 476 U.S. 79 (1986).
} 
the current Court, that the century-long struggle against jury discrimination has been fought exclusively on behalf of black defendants. ${ }^{103}$

To be sure, discrimination against black defendants was a significant Reconstruction concern. Tennessee blacks, for example, denounced "the continued, persistent and unlawful manner in which they are tried, condemned, hanged, and enslaved, by individuals who have been taught from cradle to the jury box, that the negro is naturally inferior to them."104 The president of the Convention of the Colored People of North Carolina, just months after the end of the Civil War, explicitly connected the right to serve on juries with the defendant's right to a fair trial. According to the New York Daily Tribune, which covered the Convention, President J.W. Hood argued that

[t]he Constitution of the United States, and of the several States, guaranteed to all persons accused of crime, the right of trial before a jury of his peers. The colored man was his peer, and he claimed that he should be permitted to sit on a jury where a colored man was to be tried. ${ }^{105}$

The available evidence suggests that there was reason to be concerned about unduly harsh treatment of black defendants. A study of three Georgia counties from 1866 to 1879 revealed that blacks charged with crimes were more likely to be convicted than whites charged with similar offenses. ${ }^{106}$ The sanctions imposed on black convicts were also disproportionately harsh, particularly with the advent of the chain gang and convict leasing. The new system gave counties an economic incentive to convict individuals and removed the economic burden they had experienced before the Civil War, when incarceration was the principal sanction and

103. For a discussion of modern jury discrimination jurisprudence, see Parts I and IV.

104. EDWARD L. AYERS, VENGEANCE AND JUSTICE 175 (1984) (internal quotation marks omitted). According to one white Northerner who moved south, despite "all our vigilance, the niggers will steal, and we may congratulate ourselves if they do not get the Lion's share." Id. at 176-77 (internal quotation marks omitted).

105. From North Carolina, N.Y. DAILY TRIB., Oct. 7, 1865, at 1. Georgia blacks went even further than the North Carolina Convention, arguing that all-black juries should hear cases with black parties, and that blacks should receive proportional representation in cases with parties of both races. The Freedmen's Convention of Georgia argued:

We also claim that in all cases where we are tried for legal offences between each other, a jury consisting of colored men should be empanneled [sic] for that purpose. But it is the right of every man accused of any offence, to be tried by a jury of his peers, and when the parties are absolutely colored, there could be no injustice done the white man by such a course of action, besides it would give entire satisfaction to the colored people. And even when white persons should be a party to the affair a proportional representation on the jury would be no unfair intrusion upon them.

ProceEDings of THE FreEDMEN's CONVENTION OF GEORGIA, Assembled AT Augusta 19-20 (1866).

106. See AYERS, supra note 104, at 176. 
slaveowners did not want to see their black property in jail. ${ }^{107}$ As a result, a black man might get sentenced to ninety days for petty theft - as one black New Orleans paper put it, "three days for the stealing, and eighty-seven days for being colored." $" 108$

Yet while the need to ensure equal treatment for black defendants was substantial, the most frequent theme voiced by blacks and Republicans during the Reconstruction era was the need to protect blacks from becoming victims of crime. ${ }^{109}$ As one black commentator concluded, the problem with Southern justice after the Civil War "is not so much that the negro fails to get justice before the Courts ... but too often it is that the native white man escapes it." ${ }^{110}$ In Texas, for example, there were 500 murder prosecutions of whites charged with killing blacks in 1865 and 1866 ; in the 500 trials, all-white juries acquitted every one of the white defendants. ${ }^{111}$

The connection between protecting black victims of crime and having blacks sit on juries was immediately apparent to some. As early as 1865 , during the debate over the Thirteenth Amendment, Republican Representative William Kelley of Pennsylvania referred his colleagues to the story of a black boy allegedly murdered by a white man in New Orleans. The jury acquitted the defendant. The verdict caused the black New Orleans Tribune to demand a black presence on juries. ${ }^{112}$ The Tribune, whose editorial Kelley read into the record, carefully distinguished between justice for black victims and black defendants, and argued that juries were intended to protect both. "The security afforded by the composition of a jury has to be of a twofold character," argued the editors. ${ }^{113}$ "Justice has to strike the culprit and avenge the blood of the innocent, as well as to defend the accused party against undue prejudices." 114 Given these purposes, asked the paper, "Why have we no representatives on the jury? Are our lives, honor, and liberties to be left in the hands of men who are laboring under the most stubborn and narrow prejudice? Is there any protection or justice for us at their hands?"115 Similarly, proponents of the Freedmen's Bureau

107. Id. at 177-78. For a brilliant analysis of the relationship between racism, the end of slavery, and the rise of the convict-leasing system, see DAVID M. OSHINSKY, "WORSE THAN SLAVERY": PARCHMAN FARM AND THE ORDEAL OF JIM CROW JUSTICE 1-84 (1996).

108. LEON F. Litwack, BeEN IN THE StORM So LONG: THE AfTERMATH OF SLAVERY 286 (1979) (internal quotation marks omitted).

109. See generally RANDALl KenNedy, RACE, CRIME, AND THE LAW 29-75 (1997) (documenting the unequal protection of black victims throughout American history).

110. AYERS, supra note 104, at 179 (internal quotation marks omitted).

111. Douglas L. Colbert, Challenging the Challenge: Thirteenth Amendment as a Prohibition Against the Racial Use of Peremptory Challenges, 76 CORNELL L. REV. 1, 41 (1990).

112. For a brief discussion of the history of the Tribune, see supra note 84 .

113. CONG. GLOBE, 38th Cong., 2d Sess. 289 (1865) (statement of Rep. Kelley) (quoting Is There Any Justice for the Black?, NEW ORLEANS TRIB., Dec. 15, 1864).

114. Id. (quoting Is There Any Justice for the Black?, supra note 113).

115. Id. (quoting Is There Any Justice for the Black?, supra note 113). 
argued that the Bureau was necessary to ensure the protection of black Southerners from violence at the hands of whites. ${ }^{116}$

The goal of protecting blacks from crime also influenced the debate over the Fourteenth Amendment. ${ }^{117}$ For example, Republican Senator Daniel Clark of New Hampshire, acknowledging that the white community might value some lives over others, argued that blacks needed to be protected equally:

Is [a black man] not entitled to his life as clearly and fully as the white man? That life may not be of the same consequence in the community as another life, but be it of more or less value, is not the negro just as much entitled to it as any other man can be to his? And has he not a right just as good to have it protected by law? ${ }^{118}$

116. See, e.g., Cong. Globe, 39th Cong., 1st Sess. 941-42 (1866) (statement of Sen. Trumbull); Neal Kumar Katyal, Note, Men Who Own Women: A Thirteenth Amendment Critique of Forced Prostitution, 103 YALE L.J. 791, 821 n.174 (1993). As part of its efforts, the Freedmen's Bureau set up a network of courts that handled small disputes, including criminal cases that involved fines of up to $\$ 100$ or thirty days in jail. CHRISTOPHER WALDREP, ROOTS OF DisORDER: RACE AND CRIMINAL JUSTICE IN THE AMERICAN SOUTH, 1817-80, at 101 (1998). Despite proponents' desires and the best efforts of many of its agents, the Freedmen's Bureau was unable to protect Southern blacks adequately. See AYERS, supra note 104, at 152-57; BARRY A. Crouch, The Freedmen's Bureau AND BlaCK TEXans 65-67, 76-77, 91-97 (1992); Donald G. NiEman, To Set the LAW in Motion: The FreEdmen's Bureau and the Legal Rights OF BLACKS, 1865-1868, at 13-15, 24-27, 133-47, 205-09 (1979).

117. There is substantial historical evidence that the original intent of the Fourteenth Amendment was to protect all citizens, including recently freed slaves, from private violence. See, e.g., Steven J. Heyman, The First Duty of Government: Protection, Liberty and the Fourteenth Amendment, 41 DUKE L.J. 507, 550-70 (1991). Under this view, the state action requirement under the Fourteenth Amendment would be exactly backwards, for the original intent was to protect against state inaction. See, e.g., TENBROEK, supra note 16, at 203-04; Robin West, Progressive CONSTITUtionalism: ReCONSTRUCTING THE FouRTEenth AMENDMENT 23 (1994) ("[T]he plainest possible meaning of the Fourteenth Amendment mandate that no state shall deny to any citizen 'equal protection of the law' is that no state may deny to any citizen the protection of its criminal and civil law against private violence and private violation."). There are important links to abolitionism here as well, for the physical protection of slaves was of utmost importance to the antislavery movement. Protection of personal liberty was the central tenet of antislavery advocates and "the key element of personal liberty was the right to protection of the laws; it was precisely this right that slaves were denied." William E. Nelson, The Impact of the Antislavery Movement upon Styles of Judicial Reasoning in Nineteenth Century America, 87 HARV. L. REV. 513, 537 (1974); see also WEST, supra, at 25-26 (noting the "widespread consensus among historians" that the "abolitionist meaning, or something closely akin to it, is the meaning of the equal protection clause embraced by those who most actively campaigned for its inclusion in the Constitution, from the 1830s all the way through the passage of the amendment itself').

118. CONG. Globe, 39th Cong., 1st Sess. 833 (1866) (statement of Sen. Clark). Testimony before the Joint Committee on Reconstruction also emphasized the importance of continuing federal oversight to protect the freedmen. The Reverend L.M. Hobbs, for example, testified that "I hear them making their threats, and saying that if they could get the military taken away 'there would be plenty of dead niggers lying around in the woods.' ... [T] he negroes would be shot down like sheep." Hearings of the J. Comm. on Reconstruction, 39th Cong., 1st Sess. 10-11 (1866) (statement of Rev. L.M. Hobbs). 
Despite these early appeals, the violence against blacks in the South increased following the Civil War, reaching epidemic proportions by the late $1860 \mathrm{~s}$ and early $1870 \mathrm{~s} .{ }^{119}$ The violence of this era took a variety of forms - including beatings, castration, and lynchings. ${ }^{120}$ Politically active blacks were often targets. ${ }^{121}$ One such case was the Frankfort Riot of 1871 in Kentucky. Two black men were abducted from a courthouse jail and lynched in retaliation for an angry encounter between black Republicans and white Democrats at the polls earlier in the day. The lynchings, the most publicized in Kentucky history, led to a rare investigation and prosecution. Before he was nominated to the Supreme Court, John Marshall Harlan, the state's leading Republican, represented one of the defendants. Harlan defended his role, saying he needed the money: "II once thought that I would have nothing to do with cases of this kind, but, upon reflection, I

119. See, e.g., Jonathan M. BRyant, How Curious a LAND: CONFlict AND CHANGE IN Greene CoUnTy, GeORgIA, 1850-1885, at 104-11, 120-38 (1996); W.E.B. Du BOIS, BLACK RECONSTRUCTION IN AMERICA 670-89 (Atheneum 1992) (1935); JOHN HOPE FRANKLIN \& AlFred A. MOSS, JR., From SLAVERY TO FrEEDOM: A History OF NEGRO AMERICANS 228-30 (6th ed. 1988); GeORGE C. RABle, But THERE WAS No PEACE: THE ROLE OF ViOLENCE IN THE Politics of ReCONSTRUCTION (1984); HeRbert SHAPIRO, White ViolenCE AND Black Response 5-29 (1988); Allen W. Trelease, White Terror: The Ku KluX Klan CONSPIRACY AND SOUTHERN RECONSTRUCTION (1971); GEORgE C. WRight, RACIAL VIOLENCE IN KENTUCKY, 1865-1940, at 19-60 (1990).

120. As Leon Litwack concludes,

How many black men and women were beaten, flogged, mutilated, and murdered in the first years of emancipation will never be known. Nor could any accurate body count or statistical breakdown reveal the barbaric savagery and depravity that so frequently characterized the assaults made on freedmen in the name of restraining their savagery and depravity - the severed ears and entrails, the mutilated sex organs, the burnings at the stake, the forced drownings, the open display of skulls and severed limbs as trophies.

LITWACK, supra note 108, at 276-77; see also WRIGHT, supra note 119, at 41 (noting that most scholarship has focused on lynching after Reconstruction, but marking Reconstruction as the period when the lynching era began); Emma Coleman Jordan, A History Lesson: Reparations for What?, 58 N.Y.U. ANN. SURV. AM. L. 557 (2003) (reviewing the historiography of the era's violence, outlining the history of lynching from 1865 to 1955 , and dispelling common myths regarding the lynching phenomenon); Joel Williamson, Wounds Not Scars: Lynching, the National Conscience, and the American Historian, 83 J. AM. HIST. 1221, 1232 (1997) (exploring why many historians-including Williamson himself-have overlooked lynching, and suggesting that "southern whites lynching blacks in the turn-of-the-century South while northern whites looked on is as close as America has ever come to experiencing our own holocaust"). For the most recent comprehensive history of lynching, see PHILIP DRAY, AT THE HANDS OF PERSONS UNKNOWN: THE LYNCHING OF BLACK AMERICA (2002).

121. See FONER, supra note 12, at 442-43; Herbert Shapiro, Afro-American Responses to Race Violence During Reconstruction, 36 SCI. \& SOC'Y 158, 158-61 (1972). Not all of the violence aimed at blacks had direct political links, however-at least not in the traditional definition of "politics." Martha Hodes's important work has shown that black men who gained economic power and had sexual relationships with white women were also targets. MARTHA Hodes, White Women, Black Men: Illicit SeX in the Nineteenth-Century South 157 (1997) ("Political power, economic success, and sex with a white woman-all such actions on the part of a black man confounded the lines of racial categories in a South without slavery, and therefore became unforgivable transgressions in the eyes of whites."). And while men were most often the targets of white violence, women too were brutalized. See CROUCH, supra note 116, at 224 . 
find that I must play lawyer in those as in other cases, [or] abandon good fees which I am not able to do." ${ }^{122}$ The all-white jury acquitted all the defendants, including Harlan's client. ${ }^{123}$

Blacks were not the only targets of this violence. White Republicans were also victims. After discussing a Louisiana jury's acquittal of a white man who had killed a black boy, ${ }^{124}$ Representative Kelley warned white Republicans they would be next. Kelley read the following passage from the New Orleans Tribune:

But for every Union man in the city the last verdict is a warning. In the event - as impossible as it may appear - that rebel rule should temporarily be established here, we can foresee the fate of the friends of the Union. Then, there will be no more justice, no more protection for them than for the hated negro. It will be lawful to pursue them in the streets, drown them, kill them; and no jury will be found to convict the murderers. Let the Union men understand the case, and look to a complete reform in our laws relating to the formation of the jury. ${ }^{125}$

The black press reported other allegations of violence against blacks and Republicans. The Louisianian, for example, complained of the brutal treatment of a black state senator, Edward Butler. According to the paper, Butler refused to leave the first-class cabin of a steamer when ordered to do so:

Scarcely were the words uttered, then the clerk placed his hands on him, and a crowd of men, armed with the dinner-bell, a bar of iron and knives, rushed on him, struck him ... down, cut him severely in several places about his head, and dragged him out on the guards and left him there, bleeding and suffering from his wounds, and their fiendish conduct. ${ }^{126}$

The paper argued that the attack on Butler was not an isolated incident. ${ }^{127}$ It also claimed that violence drove down the votes of blacks and Republicans

122. WRIGHT, supra note 119, at 51 (quoting Letter from John Marshall Harlan to Benjamin H. Bristow (Sept. 27, 1871) (on file with the Library of Congress)) (alteration in original).

123. Id. Blacks were prohibited from serving as jurors in Kentucky state courts at the time of the Frankfort trial. See KY. GEN. STAT. ch. 62, art. III, § 2 (Bullitt \& Feland 1881) ("No person shall be a competent juryman for the trial of criminal, penal, or civil cases in any court, unless he be a white citizen, at least twenty-one years of age, a housekeeper, sober, temperate, discreet, and of good demeanor.").

124. See supra text accompanying notes $112-115$.

125. CONG. GLOBE, 38th Cong., 2d Sess. 289 (1865) (statement of Rep. Kelley) (quoting Is There Any Justice for the Black?, supra note 113) (emphasis omitted). at 2 .

126. Another Brutal Assa[u]lt-Senator Butler Maltreated, LOUISIANIAN, Mar. 23, 1871,

127. Id. 
in Louisiana parishes, allowing Democrats to win many 1870 elections, notwithstanding a predominance of Republican voters. ${ }^{128}$ The paper called upon the federal government to take action in defense of citizens in the South. ${ }^{129}$

Faced with these reports, some in Congress looked for new ways to combat the terror and brutality visited upon blacks and Republicans. The most important attempt was the Ku Klux Klan Act of $1871 .^{130}$

\section{The Ku Klux Klan Act}

As its name implies, the Ku Klux Klan Act's principal targets were the Klan itself and the violence it perpetuated. According to Indiana Senator Oliver Morton,

This society of the $\mathrm{Ku}$ Klux is the result of a general purpose, of a matured plan for the subjugation of the South by a party that is in hostility to the Government of the United States, by the party which organized and conducted the rebellion. It proposes to gain the supremacy by driving Republicans into submission and silence, or by compelling them to fly from the State. It electioneers by murder, and persuades men by the lash and destruction of their property. It seeks to waste the courage of men and their devotion to principle by causing them to go to bed at night with a dread that they may be murdered and their houses destroyed by fire before morning. ${ }^{131}$

Even worse, said Morton, the Klan acted with complete impunity: "This organization, with these principles and using these instrumentalities, has done its work. None of its members have been punished, while they commit crimes with impunity in broad daylight, so that no man in the State feels safe." $" 132$

Morton was not the only senator to decry the government's inability to punish the Klan. After recounting a long string of atrocities committed against Republicans in the South, Ohio Senator John Sherman complained that "there is another remarkable feature of this whole proceeding, and that

128. Has the Republic a Right To Defend Its Own Life?, LOUISIANIAN, Mar. 30, 1871, at 1.

129. See Federal Authority, Louisianian, Mar. 26, 1871, at 2. According to the paper,

The time has fully arrived when the national administration should recognize and feel the importance, and the weight of responsibility which rests on it, to protect the thousands of its helpless citizens throughout the South, who can hope for no justice, no consideration, no toleration whatever from the old element in it .... Id.

130. Civil Rights (Ku Klux Klan) Act of 1871, ch. 22, 17 Stat. 13 (codified as amended in scattered sections of $10,18,28$, and 42 U.S.C.).

131. CONG. GlOBE, 42d Cong., 1st Sess. app. at 253 (1871) (statement of Sen. Morton).

132. Id. app. at 252 . 
is that from the beginning to the end in all this extent of territory no man has ever been convicted or punished for any of these offenses, not one."133 Sherman proceeded to quote from the testimony of a number of North Carolina judicial officers complaining of the difficulty in enforcing the law against the Klan. Judge Settle of the Supreme Court of North Carolina indicated that "any candid man in North Carolina would tell you it is impossible for the civil authorities, however vigilant they may be, to punish those who perpetrate these outrages."

While the Republicans attributed the inability to convict lawbreakers to a variety of causes, the most important of these was the failure of Southern juries to punish violence against blacks and Republicans. Judge Settle reported that " $[\mathrm{t}]$ he defect lies not so much with the courts as with the juries. You cannot get a conviction; you cannot get a bill found by the grand jury; or, if you do, the petit jury acquits the parties." 135 This was because

[i]n nine cases out of ten the men who commit the crimes constitute or sit on the grand jury, either they themselves or their near relatives or friends, sympathizers, aiders, or abettors; and if a bill is found it is next to impossible to secure a conviction upon a trial at the bar. I have heard of no instance in North Carolina where a conviction of that sort has taken place. ${ }^{136}$

Indeed, $\mathrm{Ku}$ Klux Klan members candidly acknowledged their willingness to disobey the law as jurors in defense of one another. According to Sherman, a Klansman might even take an oath to protect his cohort:

Question. [Did your oath include] [a]nything about getting on the jury?

Answer. Yes, sir; if we could get on the jury we could save [the defendant], do what you please.

Question. No matter what the proof?

133. Id. at 157-58 (statement of Sen. Sherman).

134. Id. at 158 (internal quotation marks omitted).

135. Id. (internal quotation marks omitted). A.W. Stone, a U.S. official and resident of Savannah, Georgia, reached a similar conclusion in 1869. According to Stone, "The condition of things in Savannah for the past year has been what I call bad, so far as the security to person and property is concerned." AYERS, supra note 104, at 174 (internal quotation marks omitted). Stone blamed juries for the failure of justice: "So far as the Judges of the Superior Court are concerned, I think they administer justice impartially . . . but I cannot say as much for the juries. I think their verdicts are more or less governed by prejudice." Id. (internal quotation marks omitted).

136. CONG. GloBE, 42d Cong., 1st Sess. 158 (1871) (statement of Sen. Sherman) (internal quotation marks omitted). 
Answer. Yes, sir; you could not bring proof enough to convict. $^{137}$

Though many Republicans had entered Reconstruction with a faith in the jury system stemming from the abolitionist commitment to juries, the unwillingness of Southern juries to punish crimes against blacks challenged that commitment. The abolitionists' belief in localism came under pressure as well. Faced with states' refusal to provide equal justice to black victims, Republicans abandoned the federalist stance that abolitionists had adopted during the fugitive slave debates in favor of a more nationalist orientation. Senator Morton, for example, defended the constitutionality of the Ku Klux Klan Act on the ground that the federal government had a responsibility to step in and enforce the law when state governments proved unable and unwilling to do so:

But it is said these crimes should be punished by the States; that they are already offenses against the laws of the States, and the matter should be left with the States. The answer to that is, that the States do not punish them; the States do not protect the rights of the people; the State courts are powerless to redress these wrongs. ... Shall it be said with any reason that it is proper to leave the punishment of these crimes to the States when it is a notorious fact that the States do not punish them? ${ }^{138}$

The black press joined in the condemnation of the states' rights position. The Louisianian ridiculed its proponents, arguing that "according to [states' rights advocates] the enemies of Equal Rights and the Constitution which uphold[s] them have only to get possession of the machinery of a State, and they may rob, maim, burn, and slay loyal Unionists with perfect impunity." 139 Citing the Supremacy Clause and the Fifteenth Amendment, the paper concluded that this vision of states' rights "is consistent neither with the spirit nor the letter of that grand Charter of our National existence." 140

For their part, representatives from the former Confederacy, many of whom had endorsed federal government intervention when it was on behalf

137. Id. (internal quotation marks omitted). As the following exchange indicates, the Klan oath extended to the witness stand as well as the jury box:

Question. Was there anything in the obligation you took, or the rules of the order, as to your being obliged to defend men by your oaths or otherwise?

Answer. Yes, sir; if he could get you in as a witness you had to swear him out, let you be swearing a lie or not. If you swore against him, why you might as well be a traveling at once.

Id. (internal quotation marks omitted).

138. Id. app. at 252 (statement of Sen. Morton).

139. Has the Republic a Right To Defend Its Own Life?, supra note 128.

140. Id. 
of slavery, now rejected federal authority. For example, Representative Henry McHenry, a Kentucky Democrat, objected to the Ku Klux Klan Act, arguing that Southern states were doing their job of enforcing the law properly and that even if they were not, the national government had no role interfering with their affairs. ${ }^{141}$

Despite the opposition of congressmen who called the congressional extension of authority unconstitutional, the Republican Congress passed the $\mathrm{Ku}$ Klux Klan Act of 1871. To many Republicans, the Act appeared to be the only way to protect blacks and white Republicans from terrorism. In addition to prohibiting conspiracies against the federal government and providing a federal cause of action for those whose federal rights were violated under color of state law, the Act directly addressed the question of biased juries. Section 5 of the Act denied jury eligibility to persons who had conspired to deny the civil rights of blacks, and provided for penalties for those who perjured themselves during jury selection. ${ }^{142}$ While some doubted the Act's efficacy, ${ }^{143}$ others believed it held great promise. ${ }^{144}$

141. McHenry argued that Southern states already had laws protecting all citizens from violence:

How can a government protect a man who has been murdered? It can punish the murderer. It can protect the man who has been assaulted and beaten only by giving him a pecuniary consideration for the injury done him. Do our States fail in these remedies? What southern State has not a penal code to punish wicked men for their crimes and misdemeanors? In my State there is not an offense in the whole catalogue of crime that is not denounced by a severe penalty; so, I presume, in all the others.

Cong. Globe, 42d Cong., 1st Sess. 431 (1871) (statement of Rep. McHenry). Moreover, concluded McHenry, even if the North did not like the manner in which those laws were enforced, it was not the role of the federal government to interfere in state criminal law:

But suppose we have failed in this: does our delinquency give another legislative power the right to interfere in our municipal regulations? Can Congress supply our legislative deficiencies any more than the Legislature of Pennsylvania can do it? If it can, the express authority to do so must be found in the Constitution. But in all this debate that power has not been pointed out. Id.

\section{Section 5 stated:}

$[\mathrm{N}]$ o person shall be a grand or petit juror in any court of the United States upon any inquiry, hearing, or trial of any suit, proceeding, or prosecution based upon or arising under the provisions of this act who shall, in the judgment of the court, be in complicity with any such combination or conspiracy; and every such juror shall, before entering upon any such inquiry, hearing, or trial, take and subscribe an oath in open court that he has never, directly or indirectly, counselled, advised, or voluntarily aided any such combination or conspiracy; and each and every person who shall take this oath, and shall therein swear falsely, shall be guilty of perjury, and shall be subject to the pains and penalties declared against that crime.

Civil Rights (Ku Klux Klan) Act of 1871, ch. 22, § 5, 17 Stat. 13, 15 (codified as amended at 42 U.S.C. $§ 1985$ (2000)).

143. For example, Senator Allen Thurman of Ohio noted that in North Carolina, a state where Ku Klux Klan lawlessness was well-documented, all of the state judges were Republicans, as were many prosecutors and sheriffs. Thurman concluded that removal to federal court with federal penalties would do little to restrain the Ku Klux Klan:

$[\mathrm{W}] \mathrm{e}$ are told that grand juries of the State will not find indictments, or if indictments are found petit juries will not convict. But will not the same people who constitute the juries in the Federal courts be those that constitute them in the State courts, unless you 
There is evidence that the Act had a significant impact. In the late 1860s and early 1870s, Klan terrorism in South Carolina, for example, was especially severe. A particularly violent series of attacks took place on March 6, 1871, in York County, South Carolina, when over forty Ku Klux Klan members began a savage rampage. ${ }^{145}$ After beating and lynching James Rainey, a leading black Republican and an officer in the all-black militia, the mob continued its assault, terrorizing black militiamen and their families. ${ }^{146}$ These and other attacks have led historian Lou Falkner Williams to conclude that "[t]he South Carolina Klan in its fury committed some of the most heinous crimes in the history of the United States." ${ }^{, 147}$ In response, President Grant sent a detachment of federal troops to the region with orders to secure the peace and round up suspects. Federal prosecutors followed the troops. The South Carolina Klan trials were to become a test of the federal government's willingness and ability to control Southern violence against the freedmen.

intend to go out of the State of North Carolina and get jurors from some other State, import them from Massachusetts, or Vermont, or Ohio, and take them down there to try the people, or unless you intend to transport these offenders, as our forefathers were transported to Great Britain for trial, and which was one of the causes of our independence? Unless you intend to do that, in plain violation of the Constitution, what more successful machinery for the conviction of crime will you have by giving the Federal courts this jurisdiction than you now have in the courts of the States?

Cong. Globe, 42d Cong., 1st Sess. app. at 220 (1871) (statement of Sen. Thurman). Senator

Sherman also questioned the efficacy of the Act, given that the juries would still be all-white:

What remedy do you offer the victims and with what punishment do you threaten the guilty?

First, the party injured may sue in the courts of the United States for money damages. Whom? Disguised outlaws. What is the use of suing them? . . You are told by judges of the courts that the grand juries are closed against you; that the petit juries are closed against you; that organized perjury is enlisted against you. You know that of all the multitude of injuries not in a single case has redress ever been meted out to one of the multitude who has been injured. And now these scourged and mutilated victims are told by this bill that they may sue these murderous outlaws for a pecuniary compensation in the courts of the United States instead of the local courts. There they will meet the same grand jury, the same petit jury, the same organized perjury; and the only advantage you give them is a United States judge, one in a State far from the witnesses to be summoned and the place of their sufferings. How hopeless, how feeble, how like a stone to these poor sufferers is this remedy. How these disguised assassins will jeer at your lawsuit.

Id. at 820 (statement of Sen. Sherman).

144. See Federal Authority, LouISIANIAN, Mar. 30, 1871, at 2 (hailing the Act "as one of the most salutory [sic] of Reconstruction adjuncts ... rendered necessary and preremptorily [sic] demanded by the needs of the times").

145. Kermit L. Hall, Political Power and Constitutional Legitimacy: The South Carolina Ku Klux Klan Trials, 1871-1872, 33 EMORY L.J. 921, 924-26 (1984).

146. Id. It is not coincidental that the Klan chose the black militia as its target, for the control of arms in the Reconstruction South was a matter of great significance. See, e.g., Robert J. Cottrol \& Raymond T. Diamond, The Second Amendment: Toward an Afro-Americanist Reconsideration, 80 GEO. L.J. 309, 345 (1991).

147. Lou Falkner Williams, The Great South Carolina Ku Klux Klan Trials, 1871-1872, at $16(1996)$. 
Jury selection was one of the first and most critical issues to arise. ${ }^{148}$ The defense, eager to limit the number of blacks on the jury and to ensure that those who did serve would be those most easily intimidated, moved to require that prospective jurors be drawn from the district in which the defendants resided. Judge Bond, the federal judge trying the case, rejected the motion, requiring that prospective jurors be drawn from throughout the state. ${ }^{149}$ Another factor that produced blacks on the jury was the $\mathrm{Ku} \mathrm{Klux}$ Klan Act's jury eligibility requirements, which excluded many of the area's whites. Judge Bond's order and the Act's disqualification provisions together produced grand juries and petit juries that were predominantly black and relatively independent of Klan influence. In all, fifteen of the twenty-one grand jurors were black and two-thirds of all the petit jurors were black, with no Klansman tried by a jury that was majority white. ${ }^{150}$ In 1871 alone, over one hundred convictions (the majority of which were guilty pleas) were returned for the Klan attacks in York County and elsewhere in the state. ${ }^{151}$

The South Carolina experience was not unique. The federal government's efforts to prosecute the Klan were largely successful, while

148. See Hall, supra note 145 , at $937-41$.

149. In so doing, Judge Bond vindicated the desires of the framers of the Ku Klux Klan Act, who had considered a jury drawn from a greater geographical area to be one of the many advantages of federal prosecutions:

The United States courts are further above mere local influence than the county courts; their judges can act with more independence, cannot be put under terror, as local judges can; their sympathies are not so nearly identified with those of the vicinage; the jurors are taken from the state, and not the neighborhood; they will be able to rise above prejudices or bad passions or terror more easily.

Cong. GloBe, 42d Cong., 1st Sess. 460 (1871) (statement of Rep. Coburn); see also Robert D. Goldstein, Blyew: Variations on a Jurisdictional Theme, 41 STAN. L. REV. 469, 509 \& n.166 (1989) (discussing the relative merits of federal and state courts).

150. Hall, supra note 145 , at 938 . It is important to note that these juries were not all-black either, meaning that individual white jurors were voting to convict.

151. Id. at 941. Although most of the cases were resolved through guilty pleas, the few that went to trial provide a remarkable snapshot of a region in rapid transformation. One of the most remarkable features of these trials before integrated juries is the extent to which the attorneys for the Klan members were unable to contain their prejudices, even when expressing them would almost certainly harm their clients. For example, Klan member Robert Mitchell was on trial for the conspiracy to murder Jim Williams, a politically active black member of the local black militia. See Williams, supra note 147 , at $74-84$. His defense was that while he wanted to participate in disarming Williams, he had not known that others would lynch him. $I d$. at 80 . Mitchell's attorneys argued to the jury that their client had every reason to want to disarm a black militia member. According to the closing argument of Maryland Senator Reverdy Johnson, who had been hired for the defense, "“[Y]ou cannot subject the white man to the absolute and uncontrolled dominion of an armed force of a colored race." Id. at 81 (quoting PROCEEDINGS IN the Ku KluX Trials at Columbia, S.C., IN THE United States Circuit Court, November TERM, 1871, at 151, 425-26 (Negro Univs. Press 1969) (1872) [hereinafter PROCEEDINGS IN THE KU KLUX TRIALS]). His co-counsel Henry Stanbery made a similar pitch, warning the jury's black members that "if you attempt to make a step in the advance of the white man, your doom is sealed." Id. at 80 (quoting ProceEdings IN THE KU KLUX TRIALS, supra, at 405-06). These arguments were unavailing; the jury of ten blacks and two whites convicted Mitchell on one of the two charged counts. Id. at 81,83 . 
they lasted. Federal prosecutors achieved over 500 jury convictions in 1872 , compared to only forty-three in $1870{ }^{152}$ "[T] record in successful prosecutions of white supremacists was extraordinary, particularly when compared to the government's previous granting of virtual immunity to such offenders." 153 Similarly, Robert Kaczorowski has concluded that federal officers may well have been "winning their struggle against Southern terrorism." "Th4 1870 s, political opposition to the Reconstruction governments, along with budgetary concerns, caused the federal government to scale back its Klan prosecutions. ${ }^{155}$ At the same time, Supreme Court decisions limited the reach of certain Reconstruction Amendments and statutes. ${ }^{156}$ As a result, federal prosecutions of the Klan declined after 1873 and were eventually abandoned in $1877 .{ }^{157}$ In sum, "[t]he North had become tired of the necessity of enforcing order and fair elections, of protecting the Negro freedman from his white neighbors, by the use of federal troops." 158

\section{The Sumner Bill: Integrating State Juries}

The success of federal prosecutions before integrated juries was a valuable lesson for those in Congress who continued to struggle to provide equal justice in the South. An increasing number of Republicans saw the disabilities that prevented blacks from serving on state juries as the central impediment to justice for blacks in the South. Over time, many came to believe that the only structural change sufficient to guarantee the equal protection of the laws would be the inclusion of blacks as jurors. In 1870, Senator Sumner introduced a bill to supplement the Civil Rights Act of $1866 .{ }^{159}$ Sumner's bill included a provision prohibiting discrimination in the selection of jurors and providing penalties for officials who disobeyed. ${ }^{160}$

152. Colbert, supra note 111 , at 55

153. Id. at 54-55.

154. ROBERT J. KACZOROWSKI, THE POLITICS OF JUdICIAL INTERPRETATION: THE FEDERAL COURTS, DEPARTMENT OF JUSTICE AND CiVIL RIGHTS, 1866-1876, at xiv (1985).

155. Id. at 107-13.

156. See, e.g., The Slaughter-House Cases, 83 U.S. (16 Wall.) 36 (1873); Blyew v. United States, 80 U.S. (13 Wall.) 581 (1872); United States v. Cruikshank, 25 F. Cas. 707 (C.C.D. La. 1874) (No. 14,897), aff'd, 92 U.S. 542 (1876), discussed in Colbert, supra note 111, at 56-61.

157. TRELEASE, supra note 119 , at $412-18$.

158. Id. at 418 .

159. See Cong. Globe, 41st Cong., 2d Sess. 3434 (1870).

160. The provision stated:

$[\mathrm{N}]$ o person shall be disqualified for service as juror in any court, national or State, by reason of race, color, or previous condition of servitude: Provided, That such person possesses all other qualifications which are by law prescribed; and any officer or other person charged with any duty in the selection or summoning of jurors, who shall exclude or fail to summon any person for the reason above-named shall, on conviction 
Many of the themes that emerge from the debates surrounding Sumner's bill still resonate over a century later. Some senators focused on the relationship between the rights of black defendants and the right to sit on the jury. Others remained focused on the central theme of the Reconstruction era: the protection of black victims. Everyone who supported the rights of blacks to sit on juries believed that the racial composition of the jury could impact the outcome of a case.

According to Vermont Republican Senator George Edmunds, "What, sir, is more necessary to peace and security in the administration of justice in the southern States... than that [colored people] should have the constitutional right to participate in the administration of justice?"161 Edmunds concluded that without the right to sit on juries, constitutional protections for criminal defendants would have little meaning for the black defendant:

Where would be the value of declaring that a colored man should have equal rights of trial by jury and equal rights of judgment by his peers, if you are to say that the jurors are to be composed of the $\mathrm{Ku}$ Klux, and that the only status the colored man shall have in court, shall be that he shall stand either as a respondent or it may be as a witness? You are to put him into the hands of his enemies for trial. ${ }^{162}$

In the same vein, Senator Sherman argued that if blacks were to be tried by juries, blacks must sit on juries:

No man can defend the exclusion by law of black men from a jury-box when you try the black man by a jury. If the black man is too degraded to sit upon a jury, he is too degraded to be tried by a jury; he ought to be disposed of in some other way. ${ }^{163}$

Sherman made explicit that in his view the right to serve on juries was not an independent right, but one that stemmed from the defendant's right to a fair trial:

It does seem to me, not that it is the right of a man to serve on a jury, but that it is the right of all men to have a fair law and rule by which men of their own race and occupation and color may serve

thereof, be deemed guilty of a misdemeanor and be fined not less than one thousand dollars, nor more than five thousand dollars.

S. 916, 41st Cong. § 4 (1870).

161. CONG. GLOBE, 42d Cong., 2d Sess. 900 (1872) (statement of Sen. Edmunds).

162. Id.

163. Id. at 845 (statement of Sen. Sherman). 
on a jury. It is the right of the accused and not the right of the trier....

Others, like Sumner, focused on black victims of crime. Sumner stressed that crimes against blacks would continue to go unpunished unless blacks served on juries. As he explained, "I am in the receipt of letters almost daily from the South, complaining of the impossibility of obtaining justice in State courts because colored fellow-citizens are excluded from the juries." 165 Sumner read from the black National Virginian, which editorialized, "Give the colored man his plain, clear, civil rights as an American citizen. Give us a measure to protect us, white and black, from a $\mathrm{Ku}$ Klux judge and jury, and you will have done your duty to us." 166 Sumner also read from a letter from the black Secretary of State of South Carolina, who claimed that the colored people of the South were seeing "their leading men assassinated" and "their wives and children brutally whipped in the dead of night by Ku Klux."

Given what black citizens and newspapers were saying, asked Sumner, "[h]ow can justice be administered throughout States thronging with colored fellow-citizens unless you have them on the juries?"168 It could not, was Sumner's answer. He added, "Denying to colored fellow-citizens their place on the juries, you actually deny them justice. This is plain, and presents a case of startling wrong. . . I say, therefore, from the necessity of the case and also from the analogy of witnesses, the courts should be opened to colored jurors." 169 The analogy to witnesses was an important one, for Sumner and his allies recognized that one of the central motivations for opening the witness box to blacks was to secure their ability to testify in cases with black victims and defendants. The right to testify was the right of the witness, but the purpose of extending the right

164. Id. Senator Morton understood the problem in this way as well:

Take the case of the State of Kentucky where colored men are not allowed to sit upon a jury. A colored man is placed upon trial. He is to be tried by a jury of white men, perhaps for a wrong inflicted upon a white person. He is to be tried by a jury that have prejudices of race against him, that are now especially, and have been for a few years past excited against him because he has been attempted to be clothed with new rights. I ask if this colored man, to be tried by a jury of white men from which all colored men are excluded, can be said in any sense to have "the equal protection of the law?" It seems to me that here we have a strong illustration. Here are more than two hundred thousand people in the State of Kentucky who have no right to sit upon a jury, although one of their own color may be upon trial. I ask any impartial mind if it can be said that these two hundred thousand people have the equal protection, the equal benefit of the law, or have an equal right under the laws of Kentucky?

Id. at 847 (statement of Sen. Morton).

165. Id. at 822-23 (statement of Sen. Sumner).

166. $I d$. at 432 (internal quotation marks omitted).

167. Id. at 430 (internal quotation marks omitted).

168. Id. at 822 .

169. Id. at 822-23. 
was to protect black parties to a case and the black community generally. As Senator Morton put it, the right to testify was "not only for his own protection, but for the protection of others." $" 170$

The issue of whether a juror's race was a relevant characteristic was also squarely presented, and in some cases divided those who supported the jury bill from those who opposed it. For some opponents of the jury bill, white juries would do justice to Negro parties. North Carolina Senator Augustus Merrimon, for example, rejected the claim that "in order to have full and free citizenship a negro must have the right to sit upon juries in the courts of the several States." ${ }^{\prime 11}$ For Merrimon, jury service was a political right, not a civil right, and was unnecessary to secure equal protection. A white person was perfectly capable as a judge or juror of administering the law "to all people without distinction for any case, according to the constitution and laws of the State where he does administer it." 172

Senator Morton expressly rejected this contention, arguing that racial bias left all-white juries inherently incapable of trying cases involving blacks. According to Morton, most Southern white men "have been educated and taught to believe that colored men have no civil and political rights that white men are bound to respect." ${ }^{, 173}$ Given these prejudices, asked Morton, how can "the colored men ... have the equal protection of the laws when the control of their right to life, liberty, and property is placed exclusively in the hands of another race of men, hostile to them, in many respects prejudiced against them"? ${ }^{174}$ For Morton, it was the recently passed Fourteenth Amendment's equal protection mandate, combined with the reality of racial prejudice, that required blacks to serve on juries. Morton took as a given that equal protection included the right to be protected from private violence. ${ }^{175}$ But, said Morton, it was not confined to that. It also meant "that all men shall be equals before the law." ${ }^{176}$ Prejudice in both the North and the South, he believed, meant that equal protection for blacks could not be achieved if juries were all-white. ${ }^{177}$

170. Id. at 820 (statement of Sen. Morton).

171. 3 CONG. REC. 1796 (1875) (statement of Sen. Merrimon).

172. Id.

173. Id. at 1795 (statement of Sen. Morton).

174. Id.

175. See id. at 1793 (rejecting the proposition that equal protection meant solely "that each man shall be equally protected or have an equal right to be protected from an assault and battery, from assassination").

176. Id.

177. See id. ("Now, I ask if with the prejudices against the colored race entertained by the white race, even in some of the Northern States and certainly in all of the Southern States, the colored man enjoys the equal protection of the laws, if the jury that is to try him for a crime or determine his right to property must be made up exclusively of the white race?"). 
The opponents of Sumner's jury bill attacked its constitutionality. ${ }^{178}$ They argued that determining the qualifications of jurors was solely the province of the states, ${ }^{179}$ while the bill's defenders generally focused on the right of Congress to pass legislation under the Privileges and Immunities Clause of the Fourteenth Amendment. ${ }^{180}$ After a series of narrow defeats, ${ }^{181}$ Sumner's jury bill finally passed in $1875 .^{182}$

\section{E. The Violence Continues}

The Sumner jury bill, like many of the Reconstruction mandates, was not fully enforced. In some jurisdictions, blacks did serve. In New Orleans between 1872 and 1878, for example, one-third of the citizens called for grand jury service were black-matching the percentage of blacks in the region's population. ${ }^{183}$ In Washington County, Texas, where blacks were approximately $50 \%$ of the population, blacks constituted about $30 \%$ of those who served on juries between 1870 and $1884 .{ }^{184}$ Blacks similarly constituted $35 \%$ of grand jurors in Warren County, Mississippi, during the

178. For a full summary of the debate over the constitutionality of Sumner's bill, see Alfred Avins, The Fourteenth Amendment and Jury Discrimination: The Original Understanding, 27 FED. B.J. 257 (1967).

179. See, e.g., CONG. GloBE, 42d Cong., 2d Sess. 760 (1872) (statement of Sen. Carpenter).

180. See, e.g., id. at 820 (statement of Sen. Morton).

181. Id. at 918-29, 3268-70, 3737-38.

182. The bill passed as section 4 of the Civil Rights Act of 1875, which provided

[t]hat no citizen possessing all other qualifications which are or may be prescribed by law shall be disqualified for service as grand or petit juror in any court of the United States, or of any State, on account of race, color or previous condition of servitude; and any officer or other person charged with any duty in the selection or summoning of jurors who shall exclude or fail to summon any citizen for the cause aforesaid shall, on conviction thereof, be deemed guilty of a misdemeanor, and be fined not more than five thousand dollars.

Civil Rights Act of 1875 , ch. 114, $\S 4,18$ Stat. 335, 336-37. The Act was struck down by the Supreme Court in the Civil Rights Cases, 109 U.S. 3 (1883).

183. Alschuler \& Deiss, supra note 12 , at 886.

184. Donald G. Nieman, African American Communities, Politics, and Justice: Washington County, Texas, 1865-1890, in LOCAL MATTERS: RACE, CRIME AND JUSTICE IN THE NINETEENTH Century South 203, 213 (Christopher Waldrep \& Donald G. Nieman eds., 2001). Nieman argues that the black presence on juries made a difference. See id. at 214 ("[D]uring the years Republicans controlled criminal justice, the conviction rates of black and white defendants were virtually the same. Sentencing also became more equitable. In most major categories of felony, blacks and whites received remarkably similar sentences."); Donald G. Nieman, Black Political Power and Criminal Justice: Washington County, Texas, 1868-1884, 55 J. S. HIST. 391 (1989). Nieman's evidence regarding the impact that black jurors had on conviction and sentencing rates casts some doubt on Benno Schmidt's hypothesis that integrating Reconstruction juries would have made matters worse for Southern blacks. See Benno C. Schmidt, Jr., Juries, Jurisdiction and Race Discrimination: The Lost Promise of Strauder v. West Virginia, 61 TEX. L. REV. 1401, 1485 (1983) (noting the potential for "retaliation and violence, both against would-be black jurors if they blocked conviction of black defendants charged with crimes against whites and against any black defendants who escaped legal sanctions in this way"). 
1870 s. $^{185}$ Though not proportional (blacks were $70 \%$ of the county's population), this was a dramatic change from the total exclusion that marked the antebellum period. ${ }^{186}$

But according to the black papers of the day, exclusion was the more common phenomenon in most counties. ${ }^{187}$ In Savannah, Georgia, for example, a letter to the editors of the Colored Tribune complained that "[n]otwithstanding the laws provide that we shall serve upon the juries, we have been constantly denied that privilege." 188 According to the Tribune,

There is not a single instance on record where a Colored juror has served upon any jury in this city or County. We have been told that for eight years past, the $n[a] m e s$ of colored men have been in the jury box, and these boxes have been exhausted time and again, and not one colored man's name has ever been drawn . . . ${ }^{18}$

The black press argued that the effects of this exclusion were devastating, especially for black victims of crime. It alleged case after case where all-white juries acquitted or failed to indict whites suspected of killing blacks. According to the Colored Tribune, for example, after a white woman reported that somebody shot into her home but could not describe the offender, a group of men on horseback began to hunt blacks. ${ }^{190}$ They shot two, killing Monday Roberts and injuring Amos Bines. A black citizen recognized the three mounted men and reported them. The grand jury, however, concluded that the black victim had come "to his death by a gunshot wound in the right abdomen, inflicted by a body of armed citizens during an attempt to arrest a dangerous outlaw. We entirely exculpate these citizens, considering the homicide the result partly of accident and partly of a mistake...." The Tribune responded by asking, "Who was this jury

185. WALDREP, supra note 116 , at 133 . Racial integration did not mean class integration, however, as landless and poor blacks and whites remained underrepresented. This exclusion was by custom and practice, rather than by law. Id.

186. Id. Like Nieman, Waldrep finds evidence that increased black involvement in the criminal justice system made a difference in a number of areas. For example, it increased the likelihood that blacks would go to court over property disputes, family law issues, and claims of crime victimization. See id. at 137-45. Regarding crime victims, Waldrep finds that " $[\mathrm{t}]$ he more firmly Republicans, especially black Republicans, controlled the courthouse, the more comfortable black crime victims felt in going to law." $I d$. at 141.

187. It is worth noting that in 1879 and 1881 , the Supreme Court handed down two decisions that undermined legislative attempts to secure a black presence on juries. In Virginia v. Rives, the Court eliminated removal to federal court as a remedy for discriminatory jury selection. 100 U.S. 313 (1880). In Neal v. Delaware, it established an extremely high evidentiary standard for proving intentional discrimination. 103 U.S. 370 (1881). For sustained discussions of the Court's interpretations of the jury discrimination laws after Reconstruction, see Colbert, supra note 111, at 65-80; and Schmidt, supra note 184, at 1414-82.

188. Our Jury Commissioners, COLORED TRIB., June 3, 1876, at 2.

189. Id. (emphasis omitted).

190. Midnight Murderers at Their Work, COLORED TRIB., Feb. 26, 1876, at 2.

191. Id. 
and where did they come from? This outrage cannot go by unnoticed .... We denounce the murder of Roberts as most wanton, and demand the arrest and trial of all concerned in the crime." ${ }^{\prime 192}$ The paper concluded by requesting federal enforcement of the laws. "The State authorities will not protect the colored men in the enjoyment of life; will the United States authorities do it? If the authorities make no effort to enforce the law, and protect the rights of life, they become as morally guilty as the murderers." 193

Juries were not the only source of official power about which the black press complained. Only one week after the grand jury had decided not to indict the white men, the Tribune reported that Amos Bines had been arrested in connection with the crime which had led to the initial attack against Bines and Roberts. ${ }^{194}$ While being held in custody, and with a guard watching, Bines was shot to death. The Tribune declared that Bines's murder was "one of the most cold blooded that has ever come to our knowledge, and for which we hold the 'guard' and authorities of Effingham county responsible." ${ }^{\prime 195}$ The Tribune concluded that until blacks sat as jurors they would never receive equal justice, noting that "[t]he same midnight marauders who kill a colored man, hold the inquest upon his body, and sit upon the juries whenever any of their number is arrested, to the exclusion of all colored men." ${ }^{, 196}$ Despite the cries of Southern blacks, however, the murders continued. Under the headline Another Willful Murder-Where Is It To End?, the next edition of the Tribune reported that a black man had been killed by two white travelers when the man refused the travelers' demand that he help them repair their broken carriage. The alleged killers were arrested, said the Tribune, but subsequently were allowed to escape. ${ }^{197}$ The Tribune denounced the escape of the two

192. Id.

193. Id. While the Tribune requested protection from the federal government, other black newspapers suggested that black citizens retaliate against their white tormentors. The Tribune recounted a story from the Wilmington Post about the whipping and beating of a man and two women by five white men. The "young woman, who was about to become a mother, was $\mathrm{st}[\mathrm{r}] \mathrm{ipped}$ upward to the waist and held to the floor, while burning sealing wax was dropped upon her body in a hundred different places." COLORED TRIB., Apr. 8, 1876, at 1 . The paper concluded that "[t]he upshot of this whole matter is plain. These ku-klux scoundrels are the veriest cowards on earth, and they should be dealt with...." Id. If the law failed, said the paper, the black community would have to punish the offenders itself:

If the law fails to administer with evenhanded justice by ku-klux officers, and nothing else will save even women from being burnt alive, let negroes try the same on those who persecute them.... Let the negroes prepare to defend themselves and wives and their families by every means at their command, and let the whites, who have anything at stake, beware!

Id.

194. Murder! Murder!, COLORED TRIB., Mar. 4, 1876, at 2

195. Id.

196. Id.

197. Another Willful Murder-Where Is It To End?, COLORED TRIB., Mar. 11, 1876, at 3. 
suspects, stating that " $[\mathrm{w}] \mathrm{hen}$ the officers of the law are thus openly corrupt and villianous [sic], the whole people become responsible for their deeds, unless they openly denounce and punish them for their malfeasance in office." 198

The onslaught of killings caused the Tribune to argue that "the situation of the colored people in Effingham is critical. Armed bands of white men scour the country at night interfering with peaceable colored citizens. The colored men are alarmed and at the same time indignant, but dare not open their mouths." 199 Blacks had no recourse. "To appeal to the law would be simply nonsense. The men who murdered Roberts, and afterwards riddled Amos Bines with balls ... and find coroners juries to obey their mandates, have nothing to fear from the law." 200

The paper alleged that indictments and convictions were forthcoming, on the other hand, when blacks were suspected of killing whites. After a grand jury returned an indictment against a black man for the murder of two white women, the Tribune remarked: "That the Grand Jury has neglected their duty is apparent to every one ...."201 The paper's point, however, was not that the black defendant was innocent but that killers of blacks were allowed to go unindicted. The paper asked its readers to "call to mind the recent slaughter of three colored men ... and to see that no presentment has been made of the matter. Our advice [t]o that Jury is to ferret out and punish crime no matter by whom committed, white and black alike ....".202

Despite the protestations of the Tribune, violence against blacks continued. Joe Morris, a politically active black in Waynesboro, Georgia, was kidnapped while being held as a prisoner of the state. The Tribune responded:

[H]is kidnapping and undoubted destruction [was] one of the most wanton and unnecessary yet recorded in our crime and outrage ridden State. For our State authorities, who are "guardians" and protectors of the lives of prisoners serving out sentences, to remain quiet and make no effort to recapture their prisoner and protect him, displays a reckless disregard for law, that looks like complicity in the crime. ${ }^{203}$

Less than two months later, the paper reported that six white men, after warning a colored teacher to leave the county because they did not want

198. Id.

199. Outlawry in Effingham County, COLORED TRIB., Mar. 18, 1876, at 3.

200. Id.

201. The Grand Jury of Effingham, COLORED TRIB., Apr. 22, 1876, at 3.

202. Id.

203. The Fate of Joe Morris, COLORED TRIB., Apr. 15, 1876, at 3. 
anyone teaching blacks, carried the teacher into the woods "where they stripped and tied him to a tree and whipped him in a most unmerciful manner, until the blood covered his body." ${ }^{204}$ Black Savannah again "cr[ies] out against these outrages against our people," said the paper. "[W]e cant [sic] get justice in the State Courts. We must have protection somewhere. We again from the depths of our soul cry out to the National Administration, in the name of God to stop these crimes against our people." 205

A case from Kentucky lends support to the Savannah paper's claims that black lives had been devalued. In April 1874 in Anderson County, Kentucky, a white man went to buy liquor at a house jointly occupied by two white families. Nobody was home when he arrived, and he decided to take a nap on the couch. Two women, occupants of the house, arrived home in the evening and discovered the stranger. Scared, they called a group of men to investigate. Upon arrival, the men fired at the napping man, killing him. In court, the men did not argue that they acted in self-defense, but claimed that they thought the stranger was a Negro. The judge dismissed the charges. ${ }^{206}$

In sum, the unwillingness of many all-white Southern juries to punish crimes against blacks and Republicans directly challenged the Reconstruction Republicans' faith in the jury. In response, rather than abandon the jury, congressional Republicans had attempted to perfect it by providing for full black participation. Despite these efforts, juries remained largely all-white, violence against blacks in the South continued at an alarming rate, and punishment was the exception. ${ }^{207}$

204. School Teacher Whipped in Bullock County, COLORED TRIB., June 3, 1876, at 2.

205. Id.

206. See WRIGHT, supra note 119 , at 54.

207. Blacks "virtually disappeared from the southern jury box by 1900 , even in counties where they constituted an overwhelming majority of the local population." Colbert, supra note 111, at 78. The failure of all-white juries to punish crimes against blacks was not an exclusively nineteenth-century phenomenon. In the late 1930s, the NAACP launched a campaign for a federal antilynching bill. In opposition, Senator James Bailey of Tennessee was candid that Southern white juries would not prosecute state officials charged with failing to prevent lynchings:

I say to the Senate that when that kind of suit is brought, in the first place, the jury in

the county is not going to bring in a verdict for the Attorney General of the United

States. Oh no. We are not going to think of doing such a thing .... I have tried cases

for 25 years in the United States and in the state courts of North Carolina, and I have never known any difference as to juries. They are a fine body of men in either court, but they are men who have a sense of loyalty to their locality and a sense of loyalty to their people.

82 CONG. REC. 77 (1937) (statement of Sen. Bailey). Senator Bailey was frequently proven correct, most famously throughout the 1960s as all-white juries failed to convict the assassins of black civil rights workers such as Medgar Evers and Sammy Younge, Jr. See Civil Rights: Hearings on S. 3296 and Related Bills Before the Subcomm. on Constitutional Rights of the Senate Comm. on the Judiciary, 89th Cong. 192-96 (1966) (listing crimes against blacks that went unpunished or lightly punished); see also JAMES FORMAN, SAMMY YOUNGE, JR.: THE FIRST Black College StUdent To DiE In THE Black LiBeration MOVEMENT (1968). 


\section{CONCLUSION}

I have suggested that the Court has not been sufficiently attentive to the nineteenth century in its jury discrimination cases. More than that, I am proposing that what the Court has missed matters. The Reconstruction era was the constitutional moment that defined the meaning of national citizenship. The process was complex and often ambiguous. Significantly, those who framed the antidiscrimination provisions in the Constitution were concerned with questions that are very much still with us. In the context of jury discrimination, the two most important are: (1) Who is harmed by all-white juries; and (2) do we prohibit jury discrimination because we think race does not matter, or do we prohibit it precisely because race matters so much?

Consider first the question of who is harmed. In Georgia v. McCollum, three whites from Dougherty County, Georgia, were charged with beating a black couple. ${ }^{208}$ The state alleged that the race of the victims was a factor in the assault. Two of the key eyewitnesses it expected to call at trial were black. ${ }^{209}$ Dougherty County lies across the state from Savannah, where over a century earlier black victims of crime condemned the all-white juries that acquitted their assailants. In 1990, the defendants no longer had the benefit of selecting their jurors from an all-white venire. But they still could-and according to the State, would - use their twenty peremptory strikes to remove all of the blacks from the jury. ${ }^{210}$ The McCollum Court prohibited this, holding that the defendant in a criminal trial, just like the prosecution, cannot use race-based peremptory challenges.

Despite the deep historical connections between the events of McCollum and the interracial violence that marked Reconstruction, the Court made no reference to the Reconstruction goal of protecting black victims. The majority ignored Reconstruction entirely. Justice Thomas at least claimed its mantle, but he too overlooked its central theme of protecting blacks from violence. Justice Thomas's resort to Reconstruction history was limited to an extended discussion of Strauder $v$. West Virginia, the Reconstruction-era case in which the Court had upheld a black defendant's challenge to a West Virginia statute excluding blacks from juries. $^{211}$ Thomas approvingly cited Strauder's concern for 'the rights of defendants" and argued that black defendants were the only group that jury discrimination legislation was intended to protect. $^{212}$ Thomas chastised the Court for prohibiting the defendant from using race-based peremptory

208. 505 U.S. 42 (1992).

209. Joint Appendix at 5, McCollum (No. 91-372).

210. See McCollum, 505 U.S. at 45.

211. 100 U.S. 303 (1880).

212. McCollum, 505 U.S. at 61 (Thomas, J., concurring in the judgment). 
strikes. In so doing, he argued, the Court had "exalted the right of citizens to sit on juries over the rights of the criminal defendant." 213

But the Reconstruction history I have presented suggests that there is another rationale for limiting the defendant from securing an all-white jury: to ensure that black victims consistently receive the equal protection that the Fourteenth Amendment and the Sumner jury bill promised. This historical approach helps reveal the true meaning of Strauder. The Strauder Court's solicitude for the defendant is understandable, since Strauder was black and since protecting black defendants from all-white juries was one of the goals of the Reconstruction jury legislation. But, as we have seen, Thomas is wrong to suggest that it was the only goal. The protection of black victims, like the victims in McCollum itself, was an equal if not greater part of the Reconstruction story.

This more complete vision of Reconstruction also serves as a response to Justice O'Connor, whose McCollum dissent makes an argument similar to that advanced by Thomas. O'Connor claims that McCollum "fail[s] to advance nondiscriminatory criminal justice." ${ }^{214}$ Again, this claim only has force to the extent that "nondiscriminatory criminal justice" is defined solely as nondiscriminatory justice for black defendants. Once the Reconstruction goal of protecting black victims is considered, McCollum can be properly understood as advancing that goal.

The failure to consider Reconstruction's legacy also impoverishes the Court's debate over whether race affects jurors. For Justice O'Connor, race (and gender) ${ }^{215}$ still matters. ${ }^{216}$ As she argues, "[I]t is by now clear that conscious and unconscious racism can affect the way white jurors perceive minority defendants and the facts presented at their trials ...."217 Moreover, suggests O'Connor, the influence of race will sometimes make more than an academic difference-it can influence the verdict itself. Our society, she argues, is yet one "where the outcome of a minority defendant's trial may turn on the misconceptions or biases of white

213. Id. at 62

214. Id. at 68 (O'Connor, J., dissenting).

215. The same debate has played out in the context of gender. See J.E.B. v. Alabama ex rel. T.B., 511 U.S. 127, 148 (1994) (O'Connor, J., concurring) ("We know that like race, gender matters."). Citing both empirical studies and common sense, Justice O'Connor argues in J.E.B. that "one need not be a sexist to share the intuition that in certain cases a person's gender and resulting life experience will be relevant to his or her view of the case." Id. at 149; see also id. at 156 (Rehnquist, C.J., dissenting) ("The two sexes differ, both biologically and, to a diminishing extent, in experience. It is not merely 'stereotyping' to say that these differences may produce a difference in outlook which is brought to the jury room.").

216. Although O'Connor has been the most outspoken on this issue, she has not been alone. See, e.g., McCollum, 505 U.S. at 61 (Thomas, J., concurring in the judgment) ("[S]ecuring representation of the defendant's race on the jury may help to overcome racial bias ....").

217. Id. at 68 (O'Connor, J., dissenting). 
jurors." 218 This logic led O'Connor to argue that mixed juries are less likely to be racially biased. According to her, "[T]here is substantial reason to believe that the distorting influence of race is minimized on a racially mixed jury." 19 For the majority, however, to accept such reasoning would necessarily mean affirming "racial stereotypes" or indulging in "assumptions of partiality based on race." ${ }^{, 20}$ For the majority, achieving a nondiscriminatory system of jury selection depends on a theory of color ${ }^{221}$ (and gender) ${ }^{222}$ blindness.

But as the leaders of Reconstruction understood, this need not be the case. As we have seen, the Reconstruction jury discrimination legislation was premised on the belief that race often matters. The impact of race was seen as the strongest argument against jury discrimination: Because all-white juries did not adequately protect black victims and defendants, blacks needed the right to serve. Recent empirical work suggests that race continues to influence jury behavior. ${ }^{223}$ The Reconstruction debates help us

218. Id. at 69; see also supra text accompanying note 8. Justice O'Connor's understanding of the ongoing relevance of race to an individual's life experiences played a central role in her recent opinion upholding the University of Michigan Law School's affirmative action plan. Note the remarkable similarity between the language of her jury opinions and her language in Grutter $v$. Bollinger: "Just as growing up in a particular region or having particular professional experiences is likely to affect an individual's views, so too is one's own, unique experience of being a racial minority in a society, like our own, in which race unfortunately still matters." $123 \mathrm{~S}$. Ct. 2325, $2341(2003)$.

219. Mc Collum, 505 U.S. at 68 (O'Connor, J., dissenting).

220. Id. at 59 (Blackmun, J.); see also supra notes 6-7 and accompanying text.

221. For discussions of the Court's views on diversity and jury deliberations, see Vikram David Amar \& Alan Brownstein, The Hybrid Nature of Political Rights, 50 STAN. L. REV. 915, 982-88 (1998); Kim Forde-Mazrui, Jural Districting: Selecting Impartial Juries Through Community Representation, 52 VAND. L. REV. 353, 368-76 (1999); Eric L. Muller, Solving the Batson Paradox: Harmless Error, Jury Representation, and the Sixth Amendment, 106 YALE L.J. 93, 96-99 (1996); and Tanya E. Coke, Note, Lady Justice May Be Blind, but Is She a Soul Sister? Race-Neutrality and the Ideal of Representative Juries, 69 N.Y.U. L. REV. 327, 333-50 (1994).

222. Just as Justice O'Connor has extended her "race matters" position to gender, the majority has extended its "race doesn't matter" theory to gender. See J.E.B. v. Alabama ex rel. T.B., 511 U.S. 127, 137-40 (1994) (rejecting the "gross generalizations" behind the claim that a man might be more sympathetic to another man, or a woman to another woman, in a particular paternity case).

223. Though underdeveloped, the social science literature on race and jury decisionmaking suggests a variety of circumstances in which race may be a factor. See Samuel R. Sommers \& Phoebe C. Ellsworth, How Much Do We Really Know About Race and Juries? A Review of Social Science Theory and Research, 78 CHI.-KENT L. REV. 997 (2003).

Although there are very few studies that include black mock jurors, those that exist tentatively suggest that black mock jurors are influenced by the race of the defendant. While black jurors are certainly willing to convict black defendants, they frequently judge white defendants more harshly than black ones. Studies of white jurors are less conclusive: Some find racial bias and others do not. Based on their review of the literature on white juror bias, Sommers and Ellsworth propose that white jurors are less likely to be racially biased in overtly racially charged cases, or when they have been otherwise reminded (through voir dire, for example) that race is an issue. Bias is more likely to present itself in "the non-race-salient, run of the mill trial in which the defendant simply happens to be Black." Id. at 1014.

Finally, one of the most important and just-emerging areas of research concerns whether the racial composition of the jury influences deliberations. One recent study suggests that integrated 


\section{see that admitting that race often still matters would not require the Court to abandon its efforts to end discrimination in jury selection.}

juries improve the quality of the deliberative process. Looking at the same facts as all-white juries, racially mixed juries tended to deliberate longer, discuss more facts of the case, and discuss racial issues. See Samuel R. Sommers, Race and Juries: The Effects of Race-Salience and Racial Composition on Individual and Group Decision-Making (2002) (unpublished Ph.D. dissertation, University of Michigan) (on file with author), cited in Sommers \& Ellsworth, supra, at 1026 n.112. Moreover, the makeup of the jury influenced juror attitudes even before deliberations began. When asked to mark their vote before deliberations began, white jurors on all-white juries were more likely to vote to convict black defendants than were white jurors on racially integrated juries. Sommers \& Ellsworth, supra, at 1028.

Significant gaps remain in the empirical research. Among them is the absence of studies on majority-black juries: The research on black jurors always involves them as minorities on majority-white juries. Similarly, there are almost no studies of jurors from minority groups other than blacks. And, other than the Baldus study made prominent in McCleskey v. Kemp, 481 U.S. 279, 286 (1987), there is no research that effectively varies the race of the victim. So while the Baldus study comprehensively shows that jurors are more likely to impose the death penalty when murder victims are white, there is no research on whether black jurors are more likely either to convict or to vote for death when victims are black. Despite these unanswered questions, the growing body of research suggests that the race of individual jurors and of the jury as a whole may make a difference in the outcome of a case. 